\title{
Noble gas solubility in silicate melts: a review of experimentation and theory, and implications regarding magma degassing processes
}

\author{
Antonio Paonita \\ Istituto Nazionale di Geofisica e Vulcanologia, Sezione di Palermo, Italy
}

\begin{abstract}
Noble gas solubility in silicate melts and glasses has gained a crucial role in Earth Sciences investigations and in the studies of non-crystalline materials on a micro to a macro-scale. Due to their special geochemical features, noble gases are in fact ideal tracers of magma degassing. Their inert nature also allows them to be used to probe the structure of silicate melts. Owing to the development of modern high pressure and temperature technologies, a large number of experimental investigations have been performed on this subject in recent times. This paper reviews the related literature, and tries to define our present state of knowledge, the problems encountered in the experimental procedures and the theoretical questions which remain unresolved. Throughout the manuscript I will also try to show how the thermodynamic and structural interpretations of the growing experimental dataset are greatly improving our understanding of the dissolution mechanisms, although there are still several points under discussion. Our improved capability of predicting noble gas solubilities in conditions closer to those found in magma has allowed scientists to develop quantitative models of magma degassing, which provide constraints on a number of questions of geological impact. Despite these recent improvements, noble gas solubility in more complex systems involving the main volatiles in magmas, is poorly known and a lot of work must be done. Expertise from other fields would be extremely valuable to upcoming research, thus focus should be placed on the structural aspects and the practical and commercial interests of the study of noble gas solubility.
\end{abstract}

Key words noble gases - solubility - degassing silicate melts

\section{Introduction}

When investigating processes involving magmas and coexisting vapor phases, a direct observation of the system is obviously impossible. The information available comes from outgassed vapors that are released at the surface

Mailing address: Dr. Antonio Paonita, Istituto Nazionale di Geofisica e Vulcanologia, Sezione di Palermo, Via Ugo La Malfa 153, 90146 Palermo (Italy); e-mail: paonita@pa.ingv.it and from fluid inclusions trapped in igneous products. This implies that the observation conditions are different from those at the source, and that the pristine gas content may be modified by chemical reactions, unless unreactive species are considered. Furthermore, degassing of the dominant volatiles $\left(\mathrm{H}_{2} \mathrm{O}, \mathrm{CO}_{2}, \mathrm{~S}, \mathrm{Cl}\right.$ and F) strongly modifies the physico-chemical properties of the magmatic system and plays an active role in driving the degassing process, whereas components at trace concentrations passively follow the evolution of the system. Among these latter, poorly soluble species mark out the degassing process evolution very well, as degassing involves the exsolution of the vapor phase where they are preferentially partitioned. All the highlighted features can be 
recognized in the geochemical group of the noble gases: they are all chemically inert and volatile, and are present in trace concentrations in magmatic systems. Moreover, their physicochemical properties gradually vary within the group with the increase in their atomic mass or size. Thus, although noble gases do not thermodynamically define the magmatic system, their abundance ratios are a very powerful tool in studying degassing processes, on a micro to a macro-scale, from magmatic intrusions to mantle outgassing and the development of atmosphere.

For these studies, noble gas solubilities are a crucial parameter and a number of investigations show a growing interest in the subject (Carroll and Draper, 1994; Carroll and Webster, 1994 and reference therein; Draper and Carroll, 1995; Chamorro-Perez et al., 1996, 1998; Shibata et al., 1996, 1998; Shackelford, 1999; Nuccio and Paonita, 2000; Paonita et al., 2000; Walter et al., 2000; Schmidt and Keppler, 2002), also thanks to the development of modern experimental and analytical technologies. Experimental devices make it possible to reproduce magmatic temperatures from atmospheric to mantle pressures, and to measure the noble gas concentrations down to parts per million (ppm). Nevertheless, technical questions that mainly concern the distinction between the dissolved and exsolved fractions of gas must be solved to obtain accurate vapor-melt partition coefficients. Moreover, available experimental data on noble gas solubility are far from exhaustive, particularly as regards helium. The existing studies only partially cover the compositional ranges of magmatic systems and possible thermo-baric conditions, thus their use in modeling natural processes has still to be optimized.

Due to their inert nature, noble gases develop van der Waals-type interactions with silicate melts and seem to display a preferentially «physical solubility» (i.e. the noble gas atom is similar to a fixed-volume sphere entering a rigid network). Nonetheless, their dissolution mechanism is not fully defined. Empirical or semi-empirical (Lux, 1987; Jambon, 1987; White et al., 1989; Chennaoui-Aoudjehane and Jambon, 1990; Carroll and Stolper, 1993; Shibata et al., 1998; Nuccio and Paonita, 2000) ap- proaches are still the most frequently used tools to describe the noble gas solubility and to extrapolate the experimental data towards complex magmatic systems, whereas statistical-mechanics models (Doremus, 1966; Studt et al., 1970; Shacklford et al., 1972) work within a very narrow range of temperature, pressure $(T$, $P)$ and composition. Current efforts also aim at investigating the structural environment of noble gas atoms inside the silicate network, promising results coming from the use of $X$-ray techniques (Wulf et al., 1999).

In this framework of growing high-quality scientific literature, this paper describes the solubility of noble gas in silicate melts, which is mainly applied to geological problems involving magma degassing in its wide range of possible conditions. Throughout the text, this paper will try to draw attention to existing literature and the main problems encountered in experiments and modeling. While stressing the importance of noble gases as tools in studying magma degassing, the paper shows two things: a) what type of data is needed for geological applications; b) which are the most promising guidelines of research for achieving these results.

\section{Experimental techniques}

The investigation of noble gas solubility in silicate materials at magmatic conditions needs to experimentally reproduce high temperature and atmospheric up to mantle pressures. Modern technology has designed and optimized resistance furnaces and Externally Heated and Internally Heated Pressure Vessels (EHPV and IHPV) to perform experiments at atmospheric pressure up to 500-600 $\mathrm{MPa}$ at magmatic temperatures. In this equipment, the noble gas under investigation is normally used as the pressure medium in the high pressure line and enters the unsealed noble-metal capsules where the sample is contained. In EHPV and IHPV experiments, noble gas can also be contained in a sealed capsule, that is loaded prior to the run by using a custom-designed loading device (Boettcher et al., 1989) or a gas-bearing material (Paonita et al., 2000). Experiments at pres- 
sure up to mantle values (several $\mathrm{GPa}$ ) have been performed using piston cylinder apparatus or multi-anvil cells. In these instruments, a sealed capsule (single or double) containing the sample and the noble gas is inserted, and high pressures are reached using a solid pressure medium.

Run duration has to be long enough to attain equilibrium. Based on the diffusion rates of noble gases, the appropriate duration ranges from hours to months, depending on the melt or glass composition and temperature (longer periods are necessary for heavy gases in silica glasses). The use of small grain sized sample powders yields a shorter diffusive walk of gas atoms in melt, because the gas penetrates through the grain interstices before melting, resulting in faster equilibration (Jambon et al., 1986; Lux, 1989; Roselieb et al., 1992).

The noble gas content in quenched samples is analyzed using different methods. The electron microprobe has been frequently used for in situ analyses of Ar or heavier noble gases (White et al., 1989; Carroll and Stolper, 1991, 1993; Montana et al., 1993; Draper and Carroll, 1995; Chamorro-Perez et al., 1996; Schmidt and Keppler, 2002), and has obtained concentration profiles in quenched glasses with a spatial resolution of around $10 \mu \mathrm{m} . X$-ray induced emission by synchrotron radiation and proton beams have been applied to the analysis of $\mathrm{Kr}$ in albite (Carroll et al., 1993b). Light gases ( $\mathrm{He}, \mathrm{Ne}$ ) cannot be detected by these methods, and bulk extraction techniques have been applied to extract the dissolved gases (Hayatsu and Waboso, 1985; Jambon et al., 1986; Lux, 1987; Broadhurst et al., 1992; Roselieb et al., 1992; Shibata et al., 1996, 1998; Paonita et al., 2000). Solid samples are melted in a vacuum line, in order to extract the dissolved volatiles. Various analytical methods are capable of measuring the amount of extracted gas, namely Gas-Chromatography (GC), Mass Spectrometry (MS) and Knudsen cell Mass Spectrometry (KMS). The main problems consist in distinguishing between gas fractions from surface adsorption or trapping in fractures, secondary fluid inclusions and truly dissolved volatiles in the silicate melt (see Roselieb et al., 1992). In order to avoid the gas fraction released from incorpo- rated bubbles, powdering of quenched glasses has been used and grain sizes below $100 \mu \mathrm{m}$ were found to be necessary to remove most of the physically trapped gas. However, an excessively small grain size could cause significant gas loss by diffusion before analysis, at least as regards helium and, in part, neon, if the samples are not analyzed within a matter of hours (Paonita et al., 2000). Stepwise degassing methods, coupled to KMS or quadrupole MS measurements, have been developed to overcome these difficulties, based on the fact that different gas contributions are extracted in different ranges of temperature (fig. 1) (Roselieb et al., 1992, 1995; Paonita et al., 2000).

In situ extraction techniques (ultra-violet laser beam) have been combined with mass spectrometry (Kelly et al., 1994; Brooker et al., 1998; Chamorro et al., 2002), and the concentration of dissolved argon in glass volumes having around a $10 \mu \mathrm{m}$ diameter size have been obtained. These methods are very promising as they are able to remove the contribution from physically trapped gas and they can be used for lighter noble gases.

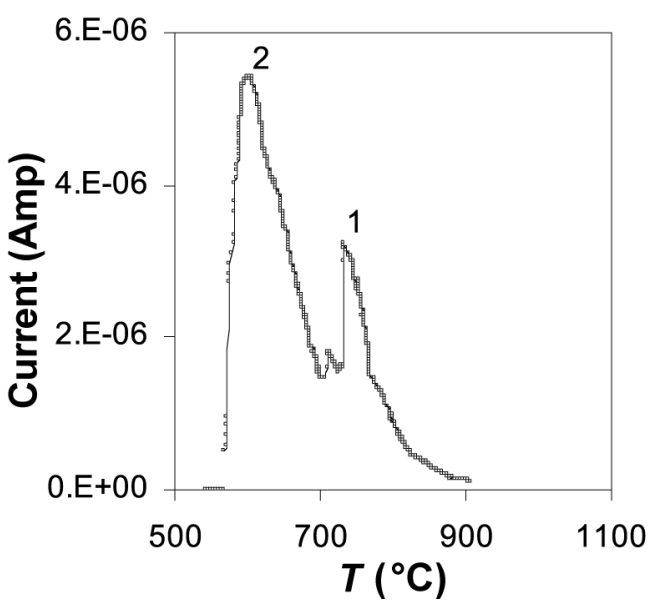

Fig. 1. Release spectrum of helium from basaltic glasses heated at a rate of $10^{\circ} \mathrm{C} / \mathrm{min}$. Data from Paonita et al. (2000). Peak 2 provides the amount of dissolved gas, whereas peak 1 has been attributed to the decrepitation of fluid inclusions. 
3. Noble gas solubility: experimental results and modeling

The main parameters affecting the solubility of noble gases in silicate melts are pressure, temperature and composition of the coexisting liquid and vapor phases. In general (see table I), the concentration of any dissolved noble gas displays a linear relation with the gas pressure up to several hundred $\mathrm{MPa}$ (figs. 2a,b and 3). At

Table I. Noble gas solubility in melt and glasses, and parameters for pressure and temperature dependence.

\begin{tabular}{|c|c|c|c|c|c|c|}
\hline & $\begin{array}{c}\text { Argon (a) } \\
\operatorname{cc}(\text { STP }) g^{-1} \text { bar }^{-1}\end{array}$ & $\begin{array}{c}P^{\circ} \\
(\mathrm{MPa})\end{array}$ & $\begin{array}{l}T^{\circ} \\
\left({ }^{\circ} \mathrm{C}\right)\end{array}$ & $\begin{array}{c}V^{\circ}\left({ }^{b}\right) \\
(\mathrm{cc} / \mathrm{mol})\end{array}$ & $\begin{array}{c}\Delta H^{\circ}\left(^{\mathrm{b}}\right) \\
(\mathrm{cal} / \mathrm{mol})\end{array}$ & Ref. \\
\hline $\mathrm{Mg}_{2} \mathrm{Si}_{2} \mathrm{O}_{6}$ & $2.0 \mathrm{E}-05$ & 0.1 & 1500 & & & 1 \\
\hline Basalt & $2.5 \mathrm{E}-05$ & 0.1 & 1200 & & & 2 \\
\hline Bas.-andes. & $9.0 \mathrm{E}-05$ & 0.1 & 1200 & & 16700 & 3 \\
\hline Tholeiite & $2.3 \mathrm{E}-05$ & 0.1 & 1200 & & & 3 \\
\hline Alk.Ol-basalt & 4.6E-05 & 0.1 & 1300 & & & 3 \\
\hline Tholeiite & $5.9 \mathrm{E}-05$ & 0.1 & 1250 & & 5700 & 4 \\
\hline Basanite & $1.0 \mathrm{E}-04$ & 0.1 & 1200 & & 4500 & 5 \\
\hline Tholeiite & $6.7 \mathrm{E}-05$ & 0.1 & 1200 & & 6800 & 5 \\
\hline Alk.Ol-basalt & $3.6 \mathrm{E}-05$ & 0.1 & 1200 & & 14200 & 5 \\
\hline Andesite & $1.5 \mathrm{E}-04$ & 0.1 & 1350 & & & 5 \\
\hline Ugandite & $4.5 \mathrm{E}-05$ & 0.1 & 1350 & & & 5 \\
\hline $\mathrm{NaAlSi}_{3} \mathrm{O}_{8}$ & $2.9 \mathrm{E}-04$ & 1500 & 1600 & 22.8 & 1962 & 6 \\
\hline $\mathrm{KAlSi}_{3} \mathrm{O}_{8}$ & $1.9 \mathrm{E}-04$ & 1500 & 1600 & 20.6 & 1722 & 6 \\
\hline $\mathrm{CaAl}_{2} \mathrm{Si}_{2} \mathrm{O}_{6}$ & $2.6 \mathrm{E}-05$ & 1500 & 1600 & 22.5 & 3373 & 6 \\
\hline $\mathrm{CaMg}_{2} \mathrm{Si}_{2} \mathrm{O}_{6}$ & $6.0 \mathrm{E}-06$ & 1500 & 1600 & 21.5 & 3421 & 6 \\
\hline $\mathrm{K}_{2} \mathrm{Si}_{4} \mathrm{O}_{9}$ & $3.2 \mathrm{E}-04$ & 1500 & 1400 & 22.6 & 3062 & 6 \\
\hline Basalt & 4.7E-05 & 1500 & 1600 & 23.1 & 2225 & 6 \\
\hline Granite & $3.9 \mathrm{E}-04$ & 1500 & 1600 & 23.7 & 3086 & 6 \\
\hline $\mathrm{SiO}_{2}$ & $1.2 \mathrm{E}-03$ & 0.1 & 700 & 16.44 & -4761 & $7,13\left({ }^{\mathrm{d}}\right)$ \\
\hline $\mathrm{NaAlSi}_{3} \mathrm{O}_{8}$ & $3.0 \mathrm{E}-04$ & 10 & 1000 & & $20\left(^{c}\right)$ & 8 \\
\hline Basalt (synt.) & 4.6E-05 & 0.1 & 1300 & & & 9 \\
\hline Rhyolite & 4.6E-04 & 0.1 & 700 & 15.6 & -1457 & $10,13\left({ }^{\mathrm{d}}\right)$ \\
\hline $\mathrm{NaAlSi}_{3} \mathrm{O}_{8}$ & $3.0 \mathrm{E}-04$ & 0.1 & 700 & 22 & -1807 & $10,13\left({ }^{d}\right)$ \\
\hline $\mathrm{KAlSi}_{3} \mathrm{O}_{8}$ & $3.0 \mathrm{E}-04$ & 240 & 700 & 22 & -3447 & 10 \\
\hline Ol-tholeiite & $4.0 \mathrm{E}-05$ & 0.1 & 1275 & 23 & & 10 \\
\hline Basalt & $9.9 \mathrm{E}-05$ & 0.1 & 1200 & 23 & & 10 \\
\hline $\mathrm{CaAl}_{2} \mathrm{Si}_{2} \mathrm{O}_{6}$ & $5.6 \mathrm{E}-04$ & $5000-12000\left(^{\mathrm{e}}\right)$ & & & & 14 \\
\hline $\mathrm{SiO}_{2}$ & $5.0 \mathrm{E}-04$ & $5000-12000\left(^{\mathrm{e}}\right)$ & & & & 14 \\
\hline NS1 $\left({ }^{\mathrm{f}}\right)$ & $1.4 \mathrm{E}-04$ & 197 & 1300 & & 5410 & 15 \\
\hline NS2 & $2.6 \mathrm{E}-04$ & 197 & 1300 & & 9690 & 15 \\
\hline NS3 & $3.4 \mathrm{E}-04$ & 197 & 1300 & & 10840 & 15 \\
\hline NCS1 & $1.4 \mathrm{E}-04$ & 197 & 1300 & & 11390 & 15 \\
\hline $\mathrm{NCS} 2$ & $1.1 \mathrm{E}-04$ & 197 & 1300 & & 11320 & 15 \\
\hline NCS3 & $6.0 \mathrm{E}-05$ & 188 & 1400 & & & 15 \\
\hline CMS1 & $2.6 \mathrm{E}-05$ & 199 & 1500 & & & 15 \\
\hline CMS2 & $2.7 \mathrm{E}-05$ & 199 & 1500 & & & 15 \\
\hline CMS3 & $2.5 \mathrm{E}-05$ & 199 & 1500 & & & 15 \\
\hline Haplogranite & $4.8 \mathrm{E}-04$ & 3800 & 1800 & 24.3 & & 17 \\
\hline Tholeiite & $1.0 \mathrm{E}-04$ & 3800 & 1800 & 24.7 & & 17 \\
\hline
\end{tabular}


Table I (continued).

\begin{tabular}{|c|c|c|c|c|c|c|}
\hline & $\begin{array}{c}\text { Helium }\left({ }^{\mathrm{a}}\right) \\
\operatorname{cc}(\text { STP }) \mathrm{g}^{-1} \mathrm{bar}^{-1}\end{array}$ & $\begin{array}{c}P^{\circ} \\
(\mathrm{MPa})\end{array}$ & $\begin{array}{l}T^{\circ} \\
\left({ }^{\circ} \mathrm{C}\right)\end{array}$ & $\begin{array}{c}V^{\circ}\left({ }^{\mathrm{b}}\right) \\
(\mathrm{cc} / \mathrm{mol})\end{array}$ & $\begin{array}{c}\Delta H^{\circ}\left({ }^{\mathrm{b}}\right) \\
(\mathrm{cal} / \mathrm{mol})\end{array}$ & Ref. \\
\hline $\mathrm{Mg}_{2} \mathrm{Si}_{2} \mathrm{O}_{6}$ & $1.2 \mathrm{E}-04$ & 0.1 & 1500 & & & 1 \\
\hline Tholeiite & $5.6 \mathrm{E}-04$ & 0.1 & 1250 & & 7100 & 4 \\
\hline Basanite & $6.8 \mathrm{E}-04$ & 0.1 & 1200 & & 1500 & 5 \\
\hline Tholeiite & $5.5 \mathrm{E}-04$ & 0.1 & 1200 & & 4900 & 5 \\
\hline Alk.Ol-basalt & $5.7 \mathrm{E}-04$ & 0.1 & 1200 & & 540 & 5 \\
\hline Ugandite & 4.8E-04 & 0.1 & 1350 & & & 5 \\
\hline $\mathrm{SiO}_{2}$ & 7.9E-03 & 0.1 & 25 & $5.5-10.8$ & -641 & $7\left(^{g}\right)$ \\
\hline \multirow[t]{3}{*}{ Basalt } & 3.8E-03 (5.1) & 215 & 1160 & & & $16\left({ }^{\mathrm{h}}\right)$ \\
\hline & $2.0 \mathrm{E}-03(3.3)$ & 125 & 1160 & & & 16 \\
\hline & 2.6E-03 (3.3) & 112 & 1160 & & & 16 \\
\hline \multirow[t]{4}{*}{ Rhyolite } & $8.6 \mathrm{E}-03(6.0)$ & 215 & 1140 & & & 16 \\
\hline & $5.4 \mathrm{E}-03(5.0)$ & 165 & 1140 & & & 16 \\
\hline & 4.4E-03 (3.9) & 112 & 1140 & & & 16 \\
\hline & $\begin{array}{c}\text { Neon }\left({ }^{\mathrm{a}}\right) \\
\operatorname{cc}(\text { STP }) \mathrm{g}^{-1} \mathrm{bar}^{-1}\end{array}$ & $\begin{array}{c}P^{\circ} \\
(\mathrm{MPa})\end{array}$ & $\begin{array}{c}T^{\circ} \\
\left({ }^{\circ} \mathrm{C}\right)\end{array}$ & $\begin{array}{c}V^{\circ}\left({ }^{\mathrm{b}}\right) \\
(\mathrm{cc} / \mathrm{mol})\end{array}$ & $\begin{array}{c}\Delta H^{\circ}\left(^{\mathrm{b}}\right) \\
(\mathrm{cal} / \mathrm{mol})\end{array}$ & Ref. \\
\hline $\mathrm{Mg}_{2} \mathrm{Si}_{2} \mathrm{O}_{6}$ & $7.0 \mathrm{E}-05$ & 0.1 & 1500 & & & 1 \\
\hline Bas.-andes. & $2.6 \mathrm{E}-04$ & 0.1 & 1200 & & 4200 & 3 \\
\hline Tholeiite & $1.9 \mathrm{E}-04$ & 0.1 & 1200 & & & 3 \\
\hline Alk.Ol-basalt & $2.2 \mathrm{E}-04$ & 0.1 & 1300 & & & 3 \\
\hline Tholeiite & $2.5 \mathrm{E}-04$ & 0.1 & 1250 & & 5000 & 4 \\
\hline Basanite & 3.6E-04 & 0.1 & 1200 & & 5100 & 5 \\
\hline Tholeiite & $2.9 \mathrm{E}-04$ & 0.1 & 1200 & & 1300 & 5 \\
\hline Alk.Ol-basalt & $1.7 \mathrm{E}-04$ & 0.1 & 1200 & & 12300 & 5 \\
\hline Ugandite & $2.1 \mathrm{E}-05$ & 0.1 & 1350 & & & 5 \\
\hline $\mathrm{SiO}_{2}$ & 4.9E-03 & 0.1 & 150 & 10.3 & -1833 & $7\left(^{g}\right)$ \\
\hline $\mathrm{NaAlSi}_{3} \mathrm{O}_{8}$ & $1.5 \mathrm{E}-03$ & 100 & 1000 & $16.8\left(^{\mathrm{d}}\right)$ & & 8 \\
\hline Basalt (synt.) & $2.8 \mathrm{E}-05$ & 0.1 & 1300 & & & 9 \\
\hline NS1 $\left({ }^{\mathrm{f}}\right)$ & $8.4 \mathrm{E}-05$ & 197 & 1300 & & 8230 & 15 \\
\hline NS2 & $1.0 \mathrm{E}-04$ & 197 & 1300 & & 9590 & 15 \\
\hline NS3 & $1.2 \mathrm{E}-04$ & 197 & 1300 & & 7250 & 15 \\
\hline NCS1 & 7.0E-04 & 197 & 1300 & & 13160 & 15 \\
\hline NCS2 & $5.0 \mathrm{E}-04$ & 197 & 1300 & & 10410 & 15 \\
\hline NCS3 & 2.6E-04 & 188 & 1400 & & & 15 \\
\hline CMS1 & $1.4 \mathrm{E}-04$ & 199 & 1500 & & & 15 \\
\hline CMS2 & $1.4 \mathrm{E}-04$ & 199 & 1500 & & & 15 \\
\hline \multirow[t]{2}{*}{ CMS3 } & $1.9 \mathrm{E}-04$ & 199 & 1500 & & & 15 \\
\hline & $\begin{array}{c}\text { Kripton }\left({ }^{\mathrm{a}}\right) \\
\text { cc(STP) } \mathrm{g}^{-1} \mathrm{bar}^{-1}\end{array}$ & $\begin{array}{c}P^{\circ} \\
(\mathrm{MPa})\end{array}$ & $\begin{array}{c}T^{\circ} \\
\left({ }^{\circ} \mathrm{C}\right)\end{array}$ & $\begin{array}{c}V^{\circ}\left({ }^{\mathrm{b}}\right) \\
(\mathrm{cc} / \mathrm{mol})\end{array}$ & $\begin{array}{c}\Delta H^{\circ}\left(^{\mathrm{b}}\right) \\
(\mathrm{cal} / \mathrm{mol})\end{array}$ & Ref. \\
\hline Basalt & $1.3 \mathrm{E}-05$ & 0.1 & 1200 & & & 2 \\
\hline Bas.-andes. & $2.1 \mathrm{E}-05$ & 0.1 & 1200 & & 19300 & 3 \\
\hline Tholeiite & 8.0E-06 & 0.1 & 1200 & & & 3 \\
\hline Alk.Ol-basalt & $1.6 \mathrm{E}-05$ & 0.1 & 1300 & & & 3 \\
\hline Tholeiite & $3.0 \mathrm{E}-5$ & 0.1 & 1250 & & 19500 & 4 \\
\hline Andesite & $1.1 \mathrm{E}-04$ & 0.1 & 1350 & & & 5 \\
\hline Basanite & $8.2 \mathrm{E}-05$ & 0.1 & 1200 & & 3700 & 5 \\
\hline
\end{tabular}


Table I (continued).

\begin{tabular}{|c|c|c|c|c|c|c|}
\hline Tholeiite & $4.8 \mathrm{E}-05$ & 0.1 & 1200 & & 9400 & 5 \\
\hline Alk.Ol-basalt & $2.1 \mathrm{E}-05$ & 0.1 & 1200 & & 19000 & 5 \\
\hline Ugandite & $3.0 \mathrm{E}-05$ & 0.1 & 1350 & & & 5 \\
\hline $\mathrm{NaAlSi}_{3} \mathrm{O}_{8}$ & $1.8 \mathrm{E}-04$ & 50 & 750 & $29\left({ }^{\mathrm{d}}\right)$ & & 8 \\
\hline Basalt (synt.) & $1.3 \mathrm{E}-05$ & 0.1 & 1300 & & & 9 \\
\hline $\mathrm{NaAlSi}_{3} \mathrm{O}_{8}$ & $1.4 \mathrm{E}-04$ & 0.1 & 800 & 25 & & 11 \\
\hline $\mathrm{SiO}_{2}$ & $3.8 \mathrm{E}-4$ & 0.1 & 800 & & & 11 \\
\hline NS1 $\left({ }^{\mathrm{f}}\right)$ & 5.7E-05 & 197 & 1300 & & 2890 & 15 \\
\hline NS2 & $1.0 \mathrm{E}-04$ & 197 & 1300 & & 16200 & 15 \\
\hline NS3 & $1.5 \mathrm{E}-04$ & 197 & 1300 & & 19190 & 15 \\
\hline NCS1 & $6.3 \mathrm{E}-05$ & 197 & 1300 & & 11840 & 15 \\
\hline NCS2 & $4.5 \mathrm{E}-05$ & 197 & 1300 & & 15020 & 15 \\
\hline NCS3 & $2.4 \mathrm{E}-05$ & 188 & 1400 & & & 15 \\
\hline CMS1 & $1.1 \mathrm{E}-05$ & 199 & 1500 & & & 15 \\
\hline CMS2 & $1.1 \mathrm{E}-05$ & 199 & 1500 & & & 15 \\
\hline \multirow[t]{2}{*}{ CMS3 } & $1.3 \mathrm{E}-05$ & 199 & 1500 & & & 15 \\
\hline & $\begin{array}{c}\text { Xenon }\left(^{\mathrm{a}}\right) \\
\operatorname{cc}(\mathrm{STP}) \mathrm{g}^{-1} \mathrm{bar}^{-1}\end{array}$ & $\begin{array}{c}P^{\circ} \\
(\mathrm{MPa})\end{array}$ & $\begin{array}{c}T^{\circ} \\
\left({ }^{\circ} \mathrm{C}\right)\end{array}$ & $\begin{array}{c}V^{\circ}\left(^{\mathrm{b}}\right) \\
(\mathrm{cc} / \mathrm{mol})\end{array}$ & $\begin{array}{c}\Delta H^{\circ}\left({ }^{\mathrm{b}}\right) \\
(\mathrm{cal} / \mathrm{mol})\end{array}$ & Ref. \\
\hline Basalt & $9.0 \mathrm{E}-06$ & 0.1 & 1200 & & & 2 \\
\hline Tholeiite & $9.0 \mathrm{E}-6$ & 0.1 & 1200 & & & 3 \\
\hline Andesite & 8.3E-05 & 0.1 & 1350 & & & 5 \\
\hline Basanite & $3.1 \mathrm{E}-05$ & 0.1 & 1200 & & 4400 & 5 \\
\hline Tholeiite & $2.5 \mathrm{E}-05$ & 0.1 & 1200 & & 2900 & 5 \\
\hline Alk.Ol-basalt & $9.2 \mathrm{E}-06$ & 0.1 & 1200 & & 14400 & 5 \\
\hline Ugandite & $1.0 \mathrm{E}-05$ & 0.1 & 1350 & & & 5 \\
\hline Basalt (synt.) & $1.1 \mathrm{E}-05$ & 0.1 & 1300 & & & 9 \\
\hline $\mathrm{NaAlSi}_{3} \mathrm{O}_{8}$ & $9.7 \mathrm{E}-05$ & 1500 & 1600 & 28.5 & 2488 & 12 \\
\hline $\mathrm{KAlSi}_{3} \mathrm{O}_{8}$ & $1.0 \mathrm{E}-04$ & 1500 & 1600 & 28 & 2560 & 12 \\
\hline $\mathrm{K}_{2} \mathrm{~S}_{\mathrm{i} 4} \mathrm{O}_{9}$ & 1.2E-04 & 1500 & 1400 & 29.4 & 3876 & 12 \\
\hline NS1 $\left({ }^{f}\right)$ & $3.5 \mathrm{E}-05$ & 197 & 1300 & & -6360 & 15 \\
\hline NS2 & $4.9 \mathrm{E}-05$ & 197 & 1300 & & 35650 & 15 \\
\hline NS3 & $7.5 \mathrm{E}-05$ & 197 & 1300 & & 30140 & 15 \\
\hline NCS1 & $2.6 \mathrm{E}-05$ & 197 & 1300 & & 11120 & 15 \\
\hline $\mathrm{NCS} 2$ & $2.2 \mathrm{E}-05$ & 197 & 1300 & & 23420 & 15 \\
\hline NCS3 & $1.2 \mathrm{E}-05$ & 188 & 1400 & & & 15 \\
\hline CMS1 & $9.3 \mathrm{E}-06$ & 199 & 1500 & & & 15 \\
\hline CMS2 & $6.2 \mathrm{E}-06$ & 199 & 1500 & & & 15 \\
\hline CMS3 & 7.2E-06 & 199 & 1500 & & & 15 \\
\hline Tholeiite & $2.8 \mathrm{E}-05$ & 3500 & 1800 & 35.76 & & 17 \\
\hline
\end{tabular}

${ }^{(a)}$ Noble gas solubility at $P^{\circ}$ and $T^{\circ}$; the dissolved concentrations are normalized by noble gas pressure. Uncertainties are normally within $10 \%$.

${ }^{(b)} V^{\circ}$ and $\Delta H^{\circ}$ are molar volume and enthalpy of solution of the reference state (see text).

( $\left.{ }^{c}\right)$ Calculated from the isothermal data of 8 by fitting eq. (3.6).

$\left({ }^{\mathrm{d}}\right)$ Solubilities and related parameters are reliable for both pure $\mathrm{Ar}$ and $\mathrm{Ar}$ in $\mathrm{He}$-Ar mixtures.

( $\left.{ }^{e}\right)$ Pressure range of the experiments.

$\left.{ }^{(}\right) \mathrm{NS}$ refers to the system $\mathrm{Na}_{2} \mathrm{O}-\mathrm{SiO}_{2}(1,2,3$ have about 35-65, 31-70, 24-77 wt\% respectively). NCS is the system $\mathrm{Na}_{2} \mathrm{O}-\mathrm{CaO}-\mathrm{SiO}_{2}(1,2,3$ have about $25-9-64,19-19-60,11-31-56$ wt $\%$ respectively). CMS is the system $\mathrm{CaO}-\mathrm{MgO}-\mathrm{SiO}_{2}$ (1, 2, 3 have about 37-8-54, 26-16-56, 14-26-59 wt\% respectively).

$\left({ }^{g}\right)$ Calculated from data from Frank et al. (1961), Shackelford et al. (1972), Shelby (1972a,b, 1976).

$\left({ }^{h}\right)$ Values in hydrous melts at $P_{\mathrm{tot}} \approx P_{\mathrm{H}_{2} \mathrm{O}}$ and $\mathrm{He}$ concentration in vapour $>0.1 \mathrm{~mol} \%$. Numbers in parenthesis are 
wt $\%$ of dissolved water. Solubilities at $P_{\mathrm{tot}} \approx P_{\mathrm{H}_{2} \mathrm{O}}+P_{\mathrm{CO}_{2}}$ were obtained at $P_{\mathrm{H}_{2} \mathrm{O}}$ very close to that given in table and do not display appreciable differences with respect to given values, therefore they were not reported.

Ref.: 1 - Kirsten (1968); 2 - Fisher (1970); 3 - Hayatsu and Waboso (1985); 4 - Jambon et al. (1986); 5 - Lux (1987); 6 - White et al. (1989); 7 - Carroll and Stolper (1991); 8 - Roselieb et al. (1992); 9 - Broadhurst et al. (1992); 10 - Carroll and Stolper (1993); 11 - Carroll et al. (1993); 12 - Montana et al. (1993); 13 - Draper and Carroll (1995); 14 - Chamorro-Perez et al. (1996); 15 - Shibata et al. (1998); 16 - Paonita et al. (2000); 17 Schmidt and Keppler (2002).
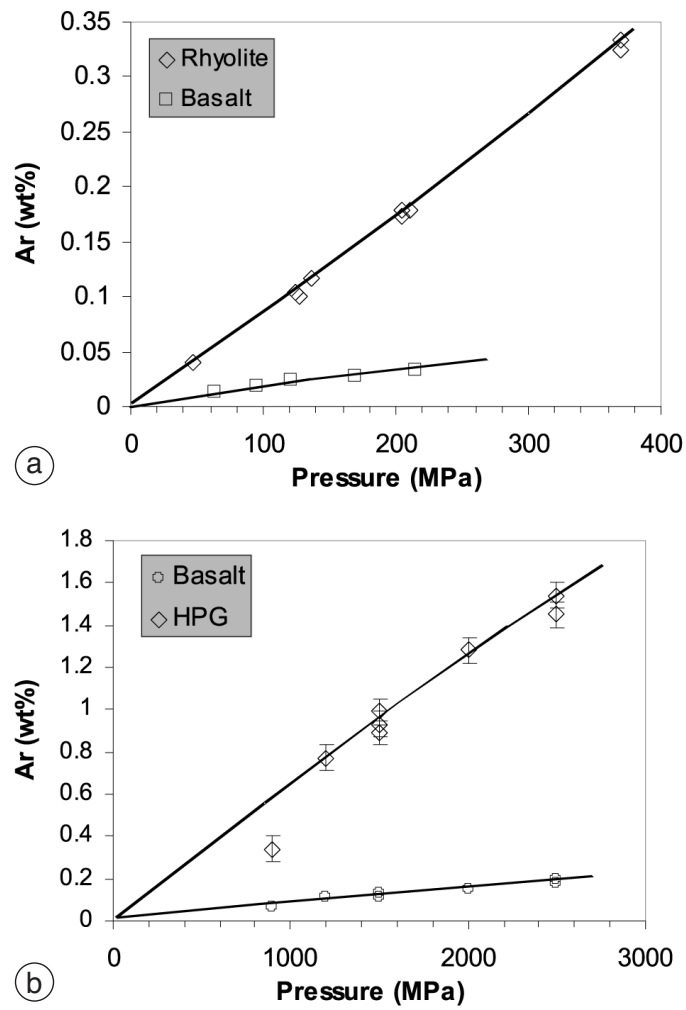

Fig. 2a,b. Dissolved Ar as a function of Ar pressure in a) rhyolite $\left(800-900^{\circ} \mathrm{C}\right)$ and basalt $\left(1200^{\circ} \mathrm{C}\right)$; b) haplogranite and basalt $\left(1500^{\circ} \mathrm{C}\right)$. Data are from Carroll and Stolper (1993) and White et al. (1989). Curves were calculated by using eq. (3.6) with parameters given in table I. The linear relation between concentration and pressure, as well as the higher solubilities in the acidic compositions, should be noted.

higher pressure, the solubility (hereafter defined as the ratio between gas concentration in melt and gas fugacity, unless differently specified) decreases, and recent experiments indicate

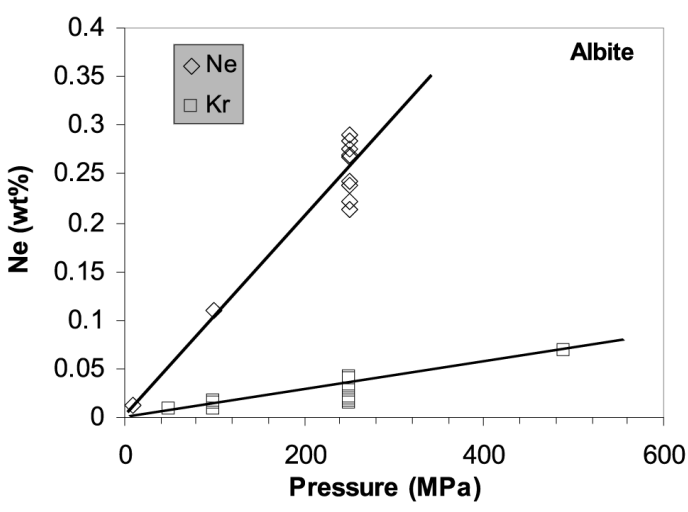

Fig. 3. Neon and krypton solubilities in albite glass at 1000 and $750^{\circ} \mathrm{C}$, respectively. Data are taken from Roselieb et al. (1992).

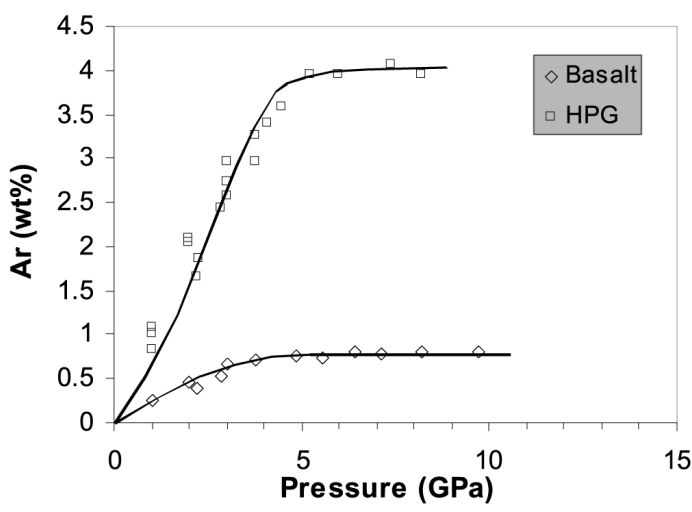

Fig. 4. Effect of very high pressure on Ar solubility in basaltic and haplogranitic melts between 1500 and $2000^{\circ} \mathrm{C}$. Data from Schmidt and Keppler (2002); curves calculated by using eq. (3.6) with the parameters given by the authors (see table I). At about 5 $\mathrm{GPa}$, dissolved $\mathrm{Ar}$ in the melt reaches a threshold concentration which does not increase even when Ar pressure is increased by some GPa. 
that a threshold concentration is reached, at least for $\mathrm{Ar}$ and $\mathrm{Xe}$, at very high pressures (4-5 $\mathrm{GPa}$ and $5 \mathrm{GPa}$, respectively, fig. 4; Schmidt and Keppler, 2002). The dependence of solubility on temperature is very modest and is often lower than the experimental uncertainties.

\subsection{Dependence on the composition of melt and glass}

The parameters which most affect the solubility of noble gases in silicate melts and glasses are the composition of the solvent and the atomic radius of the noble gas (Doremus, 1966; Shackelford et al., 1972; Shelby, 1976; Hayatsu and Waboso, 1985; Jambon et al., 1986; Lux, 1987; Broadhurst et al., 1992; Roselieb et al., 1992; Carroll and Stolper, 1993; Shibata et al., 1996, 1998; Shackelford, 1999; Paonita et al., 2000; Schmidt and Keppler, 2002). In general, solubility increases with the increasing concentration of $\mathrm{SiO}_{2}$ in the melt while smaller noble gases display higher solubilities (fig. 5). These variations suggest that noble gas atoms dissolve in holes (free spaces) of the silicate melt structure, following the so-called physical mechanism of dissolution (Doremus, 1966; Studt et al.,

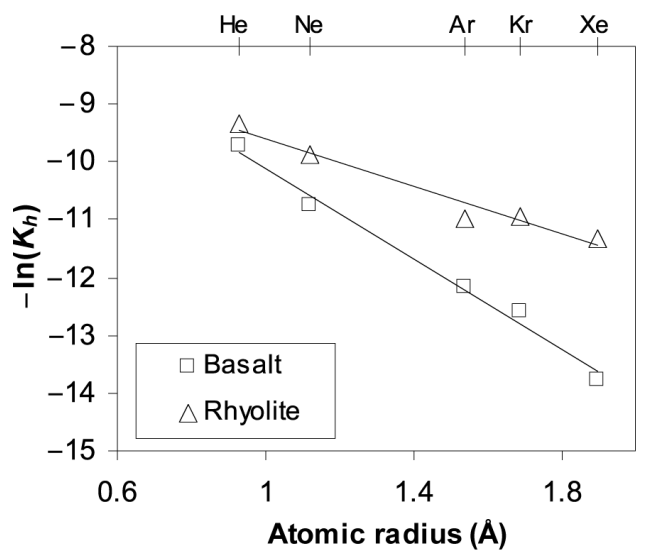

Fig. 5. Solubility (expressed under form of Henry's constant) of the noble gases as a function of their size at about $1200^{\circ} \mathrm{C}$. Solubility exponentially increases from light to heavy noble gases.
1970; Shackelford et al., 1972; Shelby, 1976). Five basic structural units form the main network of silicate melts and glasses, namely $\mathrm{SiO}_{2}$ (three-dimensional network), $\mathrm{Si}_{2} \mathrm{O}_{2}{ }^{2-}$ (sheet), $\mathrm{Si}_{2} \mathrm{O}_{6}^{4-}$ (chain), $\mathrm{Si}_{2} \mathrm{O}_{7}{ }^{6-}$ (dimer), $\mathrm{SiO}_{4}^{4-}$ (monomer) (Virgo et al., 1980). Silicon and other tetrahedrally coordinated cations $\left(\mathrm{Al}, \mathrm{Fe}^{3+}, \mathrm{Ti}^{4+}\right)$ act as network-formers, whereas $\mathrm{Na}^{+}, \mathrm{K}^{+}, \mathrm{Mg}^{2+}$, $\mathrm{Ca}^{2+}, \mathrm{Fe}^{2+}$ break the silicate polymers and thus are called network-modifiers. According to Shibata et al. (1998), the fully polymerized, threedimensional $\mathrm{SiO}_{2}$ structure of silicate melts creates a number of holes where gas atoms can be accommodated, whereas the less polymerized structures of the other units have fewer free spaces, therefore less volume is available to store gas atoms (i.e. the holes are too small). This is why silica-rich compositions display the highest noble gas solubilities. A quantitative expression of the degree of polymerization is given by the ratio $\mathrm{NBO} / \mathrm{T}$, namely the number of Non-Bridging Oxygens per atom of a Tetrahedrally coordinated cation (Brawer and White, 1975; Mysen et al., 1985). The three-dimensional network has bridging oxygens only $(\mathrm{NBO} / \mathrm{T}=0$, that is to say the highest polymerization), whereas the ratio grows when other units are present; if $\mathrm{TO}_{4}{ }^{4-}$ monomers are the only units in the melt, then $\mathrm{NBO} / \mathrm{T}=4$. Shibata et al. (1998) found a direct relationship between noble gas solubility and degree of polymerization in the silicate melts, according to which gas atoms dissolve preferentially in more polymerized, low NBO/T melts (fig. 6). They proposed the following equation to calculate the vapor-melt equilibrium constant of noble gas $i$ :

$$
\ln K_{i}=A^{\mathrm{BO}} \ln K_{i}^{\mathrm{BO}}+A^{\mathrm{NBO}} \ln K_{i}^{\mathrm{NBO}}
$$

where $A^{\mathrm{BO}}$ and $A^{\mathrm{NBO}}$ are the fraction of the units with bridging oxygens and the units with bridging and non-bridging oxygens, while $K_{i}^{\mathrm{BO}}$ and $K_{i}^{\mathrm{NBO}}$ are the equilibrium constants that refer to each group of units. The model was calibrated for noble gases from $\mathrm{Ne}$ to $\mathrm{Xe}$, but unfortunately helium was not treated. From fig. 6 it can be seen that the relationship between solubility and the NBO/T ratio is also quite evident when plotting the available experimental data for helium, 


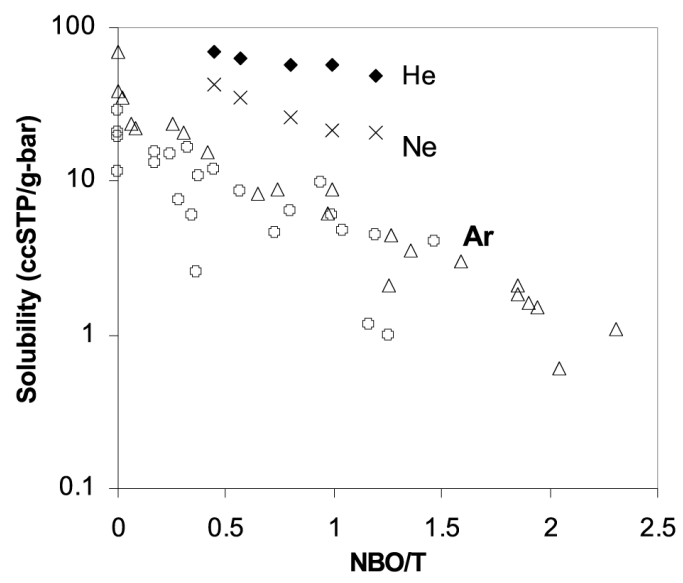

Fig. 6. Effect of melt polymerization (expressed by the NBO/T ratio, see text) on the solubility of some noble gases (modified from Shibata et al., 1998). Data for Ar are a compilation selected by Shibata et al. (1998), He and Ne from Jambon et al. (1986) and Lux (1987). Ar data are divided into two classes: $T /(T+\mathrm{Si})$ ratio higher (circles) than or lower (triangles) than 0.1 , where $T$ is the number of tetrahedrally coordinated cations other than silicon (i.e. Al, Ti). It is evident that the $\mathrm{NBO} / \mathrm{T}$ ratio fails to predict the low Ar solubilities in aluminosilicate melts.

thereby suggesting that the solubility mechanism is analogous. A similar approach has already been proposed by Jambon (1987) and Chennaoui-Aoudjehane and Jambon (1990), although no clear interpretation in terms of melt structure was given by the authors. Furthermore, even though the model by Shibata et al. (1998) does work for a large range of natural melt compositions, significant deviations from the relationship solubility-degree of polymerization occur in melts containing large amounts of $\mathrm{Al}$ (or network-formers other than $\mathrm{Si}$ ). However, the measured solubilities appear to be lower than those predicted from the NBO/T ratio (fig. 6). Although further data on noble gas solubilities in aluminosilicate melts are necessary to confirm this hypothesis, it is possible that cations ( $\mathrm{Na}, \mathrm{K}, \mathrm{Ca}, \mathrm{Mg}$ ), added to balance the surplus of negative charges due to Si versus Al substitution, occupy structural vacancies otherwise available for noble gases.
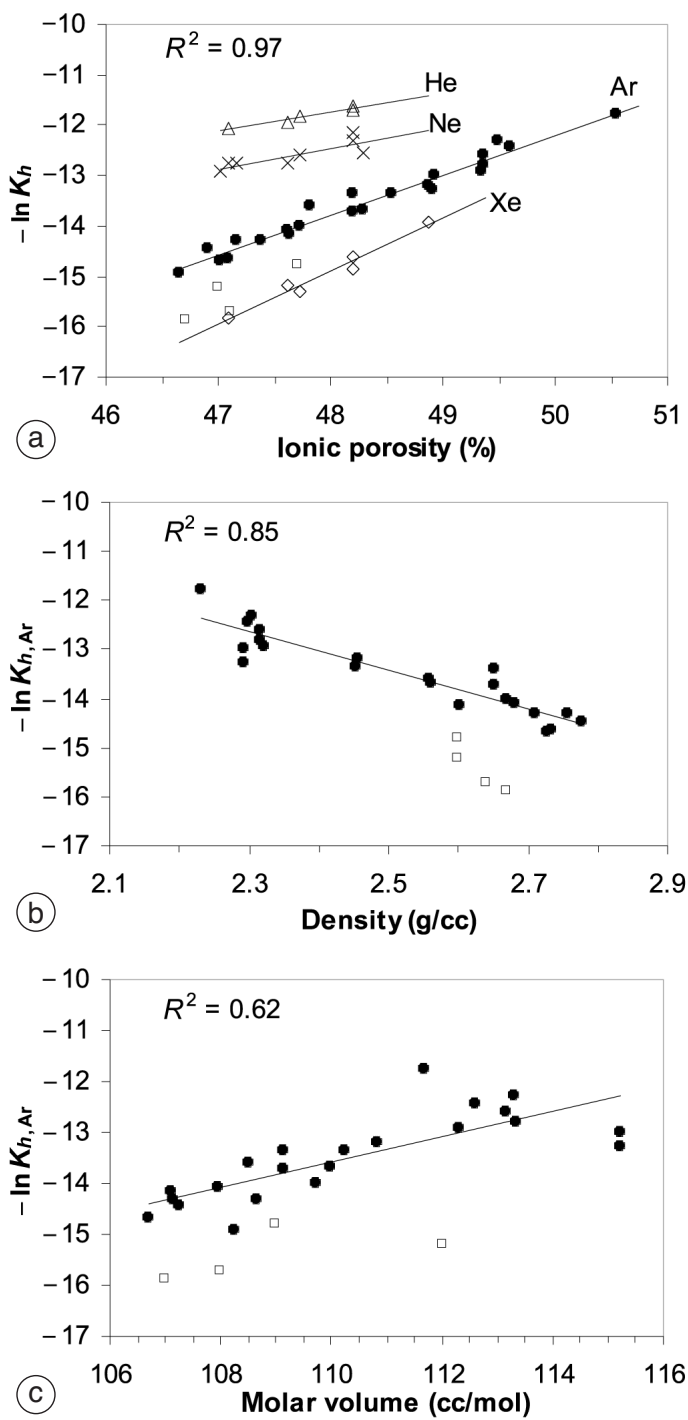

Fig. 7a-c. Relationships between noble gas solubility and a) ionic porosity of melt, b) melt density and c) melt molar volume (modified from Carroll and Stolper, 1993). In all the graphs, the squares are solubilities in $\mathrm{CaO}-\mathrm{MgO}-\mathrm{Al}_{2} \mathrm{O}_{3}-\mathrm{SiO}_{2}$ (CAMS) melts from Broadhurst et al. (1992). Henry's constant and molar volumes were computed on eight-oxygen basis melts. Linear fits of data, with the related $R^{2}$ values for Ar, are also displayed. Solubilities are much better correlated to ionic porosity than other parameters. The anomalous behavior of CAMS melts is unclear (see text for discussion). 
Based on the mechanism of interstitial dissolution in silicate networks, relationships have also been found between noble gas solubility and the physical properties of melt that give the gauge of the free space in the silicate network (fig. 7ac). In particular melt density (Lux, 1987; White et al., 1989), melt molar volume (Broadhurst et al., 1992) and melt Ionic Porosity (IP, Carroll and Stolper, 1993). Carroll and Stolper (1993) clearly show that ionic porosity works better than the other properties (density, molar volume) in predicting solubility, and is thus a better expression of the free space in the melt structure (see fig. 7a-c). In fact, ionic porosity is defined as

$$
\mathrm{IP}=100\left(1-v_{\mathrm{ca}} / v_{L}\right)
$$

where $v_{\mathrm{ca}}$ is the total volume of cations plus anions in one gram of melt and $v_{L}$ is the specific volume of melt. The relation found by Carroll and Stolper (1993) between the solubility logarithm and ionic porosity is

$$
-\ln K_{h}=m \mathrm{IP}+n
$$

where $m$ and $n$ are fitting parameters to be calibrated by linear regression of the experimentally measured solubility of the noble gas in several melt compositions, and Henry's constant $K_{h}$ is defined as

$$
K_{h}=f_{i} / x_{i}
$$

where $f_{i}$ is the noble gas fugacity in the gas phase. Carroll and Stolper (1993) estimated these parameters for all stable noble gases, by using experimental data acquired at 1000$1400^{\circ} \mathrm{C}$ and $0.1 \mathrm{MPa}$. In spite of its general accomplishment, ionic porosity fails to predict solubility in $\mathrm{CaO}-\mathrm{MgO}-\mathrm{Al}_{2} \mathrm{O}_{3}-\mathrm{SiO}_{2}$ (CMAS) melts. Furthermore, although it estimates the overall free volume in melt, the same volume could be distributed either in a few large holes or in many small cavities. Following Shibata et al. (1998), the incorporation of networkmodifier cations probably generates a kind of free space that is unable to accommodate noble gas atoms (i.e. too small interstitial sites).

Nearly all of the available experimental data (Carroll and Webster, 1994 and reference there- in; Draper and Carroll, 1994, 1995; ChamorroPerez et al., 1996, 1998; Shibata et al., 1996, 1998; Shackelford, 1999; Walter et al., 2000; Schmidt and Keppler, 2002) have been obtained by equilibrating a silicate liquid with a gas phase composed of solely noble gases, which introduces a large uncertainty in the determination of the real solubility of noble gases in magmas. In fact, the gas phases coexisting with magmas are normally $\mathrm{H}_{2} \mathrm{O}-\mathrm{CO}_{2}$ dominated vapors; more rarely, sulfur can reach several percents, whereas halogens and $\mathrm{N}_{2}$ remain minor components and the noble gases occur in trace concentrations (Gerlach and Nordlie, 1975; Giggenbach, 1996). Even at some GPa of total pressure, the partial pressures of noble gases are very low (a few bars; Carroll and Webster, 1994). In a recent article, Paonita et al. (2000) experimentally investigated the effect of $\mathrm{H}_{2} \mathrm{O}$ and $\mathrm{CO}_{2}$ on helium solubility, in order to simulate data at more geologically relevant conditions. They measured the

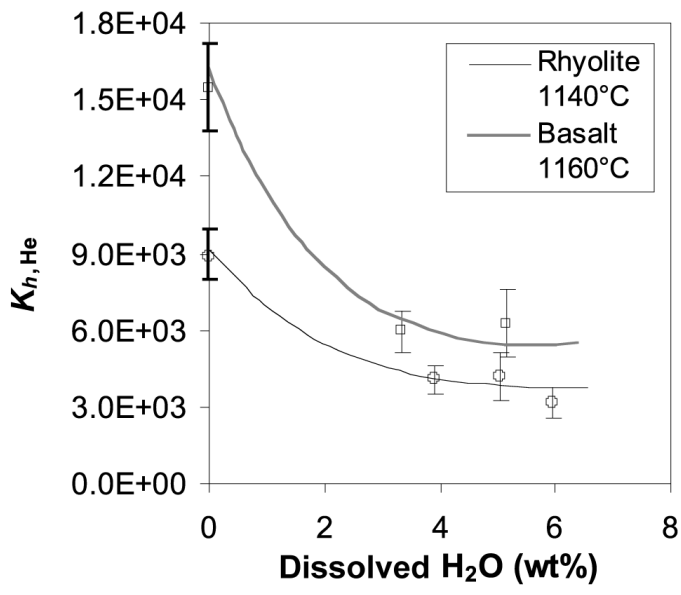

Fig. 8. Effect of dissolved water concentration on the helium Henry's constant, the latter expressed in MPa and calculated on 8-oxygen basis melt (modified from Nuccio and Paonita, 2000). Experimental data (symbols) from Paonita et al. (2000) were obtained in the condition $P_{\mathrm{tot}} \approx P_{\mathrm{H}_{2} \mathrm{O}}$ in the range 100$200 \mathrm{MPa}$, and about $0.1 \mathrm{~mol} \% \mathrm{He}$ in the vapor. Curves were computed by using the model by Nuccio and Paonita (2000), which accounts for the effect of $\mathrm{H}_{2} \mathrm{O}$ and $\mathrm{CO}_{2}$ on both noble gas solubility in melt and fugacity in vapor (see text). 
isothermal He solubility in basaltic and rhyolitic melts at pressures of 100 up to $200 \mathrm{MPa}$, in the presence of mixed $\mathrm{H}_{2} \mathrm{O}-\mathrm{CO}_{2}$ vapors ( 0 to 50 mol\% $\mathrm{H}_{2} \mathrm{O}$ ) with $\approx 0.1 \mathrm{~mol} \% \mathrm{He}$. The solubility increased by about a factor of three with $3 \mathrm{wt} \%$ $\mathrm{H}_{2} \mathrm{O}$ added to the melt, whereas a further addition of water, up to $6 \mathrm{wt} \%$, seemed to have very little effect on the solubility (fig. 8). The effect of $\mathrm{CO}_{2}$ addition (up to $0.05 \mathrm{wt} \%$ ) was within the experimental uncertainties or slightly negative. Based on these data, Nuccio and Paonita (2000) found that the helium solubility is in very good agreement with the model of Carroll et al. (1993) (eq. (3.3) with the same parameters as those for dry melts, fig. 9), provided that the ionic porosity melt is computed by taking into account the presence of dissolved $\mathrm{H}_{2} \mathrm{O}$ and $\mathrm{CO}_{2}$ (namely the $\mathrm{H}_{2} \mathrm{O}$ and $\mathrm{CO}_{2}$ partial molar volumes). It is obvious that the $\mathrm{H}_{2} \mathrm{O}$ and $\mathrm{CO}_{2}$ concentrations in the coexisting gas and liquid phase must be constrained by the solubility of these two volatiles. Nuccio and Paonita coupled their model to the thermodynamic model by Papale (1999) for solubility of $\mathrm{H}_{2} \mathrm{O}-\mathrm{CO}_{2}$ mixed vapors in silicate melts. They obtained the following equation for ionic porosity:

$$
\mathrm{IP}=100\left\{1-\frac{\frac{4}{3} \pi \sum_{\mathrm{ion}=1}^{I} r_{\mathrm{ion}}^{3} i_{\mathrm{ion}}}{x_{\mathrm{CO}_{2}}\left[\nu_{\mathrm{CO}_{2} P, T}^{\circ}+\frac{\left(1-x_{\mathrm{CO}_{2}}\right)}{P} \sum_{i=1}^{n} x_{i} w_{i \mathrm{CO}_{2}}\right]+}\right.
$$

$$
\begin{aligned}
& +\sum_{\substack{z=1 \\
z \neq \mathrm{CO}_{2}}}^{n} x_{z}+\left\{v_{z P, T}^{\circ}+x_{\mathrm{CO}_{2}}\left[\left(1-x_{z}\right) \frac{w_{z \mathrm{CO}_{2}}{ }^{1}+}{P}+\right.\right. \\
& \left.\left.-\frac{1}{P} \sum_{\substack{j=1 \\
j \neq z, \mathrm{CO}_{2}}}^{n} x_{j} w_{j \mathrm{CO}_{2}}{ }^{1}\right]\right\}
\end{aligned}
$$

where $r$ and $i$ are ionic radius and molar fraction of each of the $I$ ions forming the melt; $x$ and $v^{\circ}$ are the molar fraction and the reference molar volume of each of the $n$ oxides in melt at $P$ and $T$, and $w_{i, \mathrm{CO}_{2}}$ are binary interaction coefficients between dissolved $\mathrm{CO}_{2}$ and other oxides $\left(w_{i, \mathrm{CO}_{2}}\right.$ values are taken from Papale, 1999; reference molar volumes of oxides are from Lange and Charmichael, 1987; and ionic radii from Shannon and Prewitt, 1969). By inserting the ionic porosity

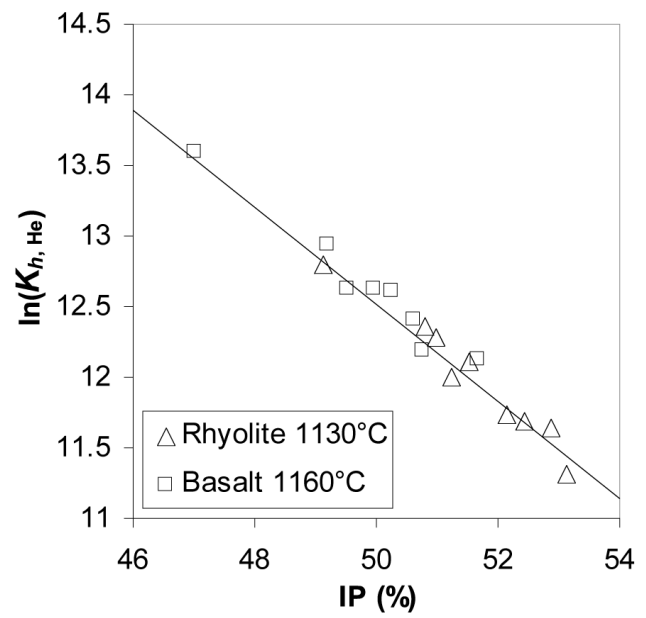

Fig. 9. Relationship between helium solubility $\left(K_{h}\right.$ in $\mathrm{MPa}$ and on 8-oxygen basis melt) versus Ionic Porosity (IP) in $\mathrm{H}_{2} \mathrm{O}$ and $\mathrm{H}_{2} \mathrm{O}-\mathrm{CO}_{2}$ bearing silicate melts $\left(\mathrm{H}_{2} \mathrm{O}\right.$ and $\mathrm{CO}_{2}$ contents up to 6 and $0.05 \mathrm{wt} \%$, respectively). IP was calculated by taking into account the effect of the main volatiles (see text). Line was calculated by using eq. (3.3) with $m$ and $n$ parameters in Carroll and Stolper (1993) for dry melts, and it displays a very good agreement with the experimental data (data from Paonita et al., 2000).

value from eq. (3.5) into eq. (3.3), the helium Henry's constant can be considered valid for $\mathrm{H}_{2} \mathrm{O}-\mathrm{CO}_{2}$ bearing melts. The empirical parameters $m$ and $n$ were the same as those obtained for dry melts (fig. 9). In order to calculate the helium concentration in the melt by eq. (3.4), the authors computed the noble gas fugacity by using a modified Redlich-Kwong equation of state for the $\mathrm{H}_{2} \mathrm{O}-\mathrm{CO}_{2}$-noble gas (De Santis et al., 1974).

With the Nuccio and Paonita (2000) model, you can theoretically calculate the solubility of other noble gases by assuming that $m$ and $n$ parameters in eq. (3.3) are the same as those for dry melts. Although the last assumption has only been experimentally confirmed for $\mathrm{He}$, due to the lack of experimental data, the authors predicted that the solubilities would also increase with water addition, and become similar when 6-7 wt $\% \mathrm{H}_{2} \mathrm{O}$ are dissolved in melt.

The relation between He solubility and water content of the melt can be tentatively dis- 
cussed from a structural point of view. Water dissolution mainly occurs as $\mathrm{OH}^{-}$groups at low concentrations of dissolved $\mathrm{H}_{2} \mathrm{O}$, whereas molecular $\mathrm{H}_{2} \mathrm{O}$ becomes more and more important with increasing water content in basaltic to rhyolitic melts (McMillan, 1994; Dixon et al., 1995; Nowak and Behrens, 1995, 2001; Ihinger et al., 1999; Withers et al., 1999; King and Holloway, 2002). Although it is generally accepted that water depolymerizes silica and alkali-silicate compositions, a similar effect is not clear in aluminosilicate melts (such as magmas). As first recognized by Sykes and Kubicki (1993), water could break Si-O-Al bonds and have a depolymerizing effect on the network. On the contrary, the Si-O-Al bond could be maintained, but weakened by the formation of a hydrogen bond, following which the silicate network would undergo merely modest deformations (Kohn et al., 1989, 1998; Oglesby et al., 2001). Based on recent studies (Zeng et al., 1999, 2000; Schmidt et al., 2000, 2001), both mechanisms could occur in the melt. In fact, the significant effect of $\mathrm{OH}^{-}$formation on He solubility matches better the hypothesis of significant structural changes rather than small deformations, suggesting that noble gases can provide valuable insights into the structure of aluminosilicate melts. We are unable to evaluate whether or not Shibata et al.'s approach (1998) predicts the observed increase in the solubility of helium, because the uncertainties regarding the structural effect of water and its depolymerizing role prevent us from obtaining a reliable estimation of the $\mathrm{NBO} / \mathrm{T}$ ratio in water-bearing melts. On the other hand, the higher He solubility is consistent with the calculated increase in the ionic porosity due to the addition of water. At higher concentrations of dissolved water, helium solubility seems to decrease with the increase of the molecular $\mathrm{H}_{2} \mathrm{O} / \mathrm{OH}$ ratio, suggesting that the $\mathrm{H}_{2} \mathrm{O}$ molecules probably occupy free spaces in the silicate structure.

\subsection{Pressure and temperature effects}

Equilibrium partitioning of noble gases between vapor and silicate melt has been described using the following thermodynamic re- lation, which is based on the equality condition of the chemical potential of the gas species in vapor and liquid phases

$$
\begin{aligned}
& \ln \frac{a_{P, T}}{f_{P, T}}=\ln \frac{a_{P^{\circ}, T^{\circ}}^{\circ}}{f_{P^{\circ}, T^{\circ}}}-\frac{\Delta H_{P^{\circ}, T}^{0}}{R}\left(\frac{1}{T}-\frac{1}{T^{\circ}}\right)+ \\
& -\frac{V_{P, T}^{0}}{R T}\left(P-P^{\circ}\right)
\end{aligned}
$$

where $a$ and $f$ refer to the activity of the noble gas in melts and its fugacity in vapor; $P^{\circ}$ and $T^{\circ}$ are the standard state conditions; $\Delta H_{P^{\circ}, T}^{0}$ is the enthalpy of dissolution of the noble gas at $P^{\circ}$ and $T ; V_{P, T}^{0}$ is the molar volume of noble gas in its reference state at $P$ and $T$, and $R$ is the gas constant. Noble gas fugacity is normally computed, as a function of $P$ and $T$, by using a modified Redlich-Kwong equation of state (Holloway, 1977).

The parameters $a^{\circ} / f^{\circ}, V^{\circ}$ and $\Delta H^{\circ}$ must be calibrated using experimental data for each noble gas as a function of pressure, temperature and silicate melt composition. Use of eq. (3.6) and the consequent parameter estimation depends on the theoretical model adopted for the dissolution process. Based on the previous considerations concerning the physical dissolution of the noble gases, one can hypothesize that noble gas atoms dissolve into a fixed population of holes in the silicate melt network. One can also assume that the available sites for a given noble gas are identical, that their number is independent of $T$ and $P$, and that gas atoms do not influence each other reciprocally. This allows us to define an activity-composition relation, namely $a=n /(N-n)$, where $n$ is the number of dissolved atoms and $N$ is the number of available sites in the melt, referenced to a hypothetical reference state of pure noble gas. By fixing the temperature and assuming that the volume of any solubility site is unchanged after the dissolution of a noble gas atom (namely, $V^{\circ}=0$ ), eq. (3.6) and the previous definition of activity can be combined to obtain the well-known formalism of the Langmuir adsorption isotherm

$$
K_{L}(T)=n /(N-n) f
$$

where $K_{L}(T)$ indicates that the equilibrium constant depends on temperature. The above for- 
malism has been widely applied to describe noble gas solubility in melts and glasses by considering the number of sites as a parameter to be evaluated (Shelby, 1976; Roselieb et al., 1992; Carroll and Stolper, 1991; Walter et al., 2000). The very high-pressure experiments recently performed by Schmidt and Keppler (2002) reached a threshold Ar concentration at which the dissolved gas content did not increase with increasing Ar pressure in either silicic or tholeiitic melts (fig. 4). The authors suggested that the sites available to store the Ar atoms were fully occupied, therefore the $N$ value was accordingly constrained to $13.8 \times 10^{20}$ sites $/ \mathrm{cm}^{3}$ and the obtained Langmuir constant was able to fit the data very well. Approximating the structure of the granitic liquid as a tridymite-like network, the number of interstitial holes can also be computed. When comparing such a number with the $N$ value obtained by Schmidt and Keppler, the latter represents only $60 \%$ of the interstitial holes. This underlines the fact that only a fraction of the holes is available to accommodate Ar atoms. In accordance with its much more compact structure, the estimated $N$ value in the tholeiitic melt was almost one order of magnitude lower $\left(3.1 \times 10^{20}\right.$ sites $\left./ \mathrm{cm}^{3}\right)$. The number of holes available for the physical dissolution of Xe was also significantly lower than that for Ar, which is consistent with the larger size of the former. Although the Langmuir isotherm was successfully applied, noble gas dissolution could violate one of its main assumptions, namely that gas atoms do not affect the structure of the solvent $\left(V^{\circ} \neq 0\right)$. In fact, a recent $X$-ray absorption spectroscopy study investigated the structural environment of dissolved krypton in vitreous silica, revealing that $\mathrm{Kr}$ atoms are coordinated by oxygen atoms having a characteristic geometry (Wulf et al., 1999): thus, $\mathrm{Kr}$ atoms create or adjust to their own solubility sites. However, whether or not smaller gas atoms have a similar network-modifier role must be verified.

Models involving additional parameters which also contain information on the structure of the silicate network have been developed following statistical-mechanical approaches (Doremus, 1966; Studt et al., 1970; Shackelford et al., 1972). In addition to the number of sites, these models include the vibrational frequency of the dissolved atom, which is treated as a harmonic oscillator in the structural cavity, and the binding energy to the interstitial hole. In silica glass, these two parameters depend upon the atomic size of the noble gas (lower frequency and more negative binding energy for larger noble gases; Shelby, 1976; Shackelford and Brown, 1980; Nakayama and Shackelford, 1990). A sharp increase in the binding energy and decrease in the vibrational frequency were obtained along the join $\mathrm{Na}_{2} \mathrm{O}$ $\mathrm{SiO}_{2}$ when moving from the silica-rich to the sodium-rich edge of the miscibility gap (Shelby, 1973). This is in agreement with both the stronger structural constraints and the necessity to spend energy in creating adequate holes in a less polymerized solvent (see also below).

A different theoretical approach in applying eq. (3.6) considers that the units of the silicate melt and noble gas atoms mix ideally. In this case, the activity of the dissolved gas is equal to its molar fraction when a Henrian reference state of pure noble gas is assumed (a hypothetical material composed by noble gas arranged like a silicate melt). The two parameters $V^{\circ}$ and $\Delta \mathrm{H}^{\circ}$ define the dependence of the solubility on $P$ and $T$, respectively (see table I). Considering them as constants in the fitting procedure, the model is generally able to successfully reproduce the experimental data in a large range of $P$ and $T$ conditions (Lux, 1987; White et al., 1989; Carroll and Stolper, 1991, 1993; Draper and Carroll, 1995; Shibata et al., 1998; Schmidt and Keppler, 2002). The calculated molar volumes for heavy noble gases (Ar, Xe) in melts are comparable to their respective co-volumes in MRK equations (the parameter named $b$ ), which reflects the atomic volume (White et al., 1989; Schmidt and Keppler, 2002). Slightly lower values than the co-volumes were determined in glasses (Carroll and Stolper, 1991, 1993; Draper and Carroll, 1995), suggesting that the noble gases fit into pre-existing holes and only a small amount of new space must be created in the melt. Similar results were found for helium in glasses, which displays $V^{\circ}$ values lower than its co-volumes (Carroll and Stolper, 1991). The small $V^{\circ}$ values of the noble gases account for their Henrian behavior at low pressure (at least up to some hundreds of $\mathrm{MPa}$ ), due 
to the negligible weight of the $V^{\circ}\left(P-P^{\circ}\right) / R T$ term in eq. (3.6). The Ar molar volumes computed for different melts (tholeiite to granitic melts; White et al. 1989, Schmidt and Keppler 2002) display a negligible dependence on the liquid composition, suggesting that a similar environment surrounds the dissolved atom in spite of the notable structural differences of the silicate structure.

The heat of the solution $\left(\Delta H^{\circ}\right)$, in both glasses and melts, is generally small (see table I), and experimental data show that temperature dependence is close to that of the experimental uncertainties. Negative $\Delta H^{\circ}$ values, namely decreasing solubility at increasing temperature, have been estimated for silicate glasses (Shackelford et al., 1972; Shelby, 1972a,b; Carroll and Stolper, 1991; Draper and Carroll, 1995) with compositions from albitic and rhyolitic up to fused silica (fig. 10). Increasing $\mathrm{Na}_{2} \mathrm{O}$ and $\mathrm{K}_{2} \mathrm{O}$ concentrations to above $20 \mathrm{~mol} \%$ seem to invert this solubility-temperature relation (Shelby, 1973, 1974). On the other hand, a positive enthalpy of solution and a positive direct temperature dependence of solubility have normally been measured in basaltic melts (Lux, 1987; Jambon et al., 1986; Hayatsu and Waboso, 1985;

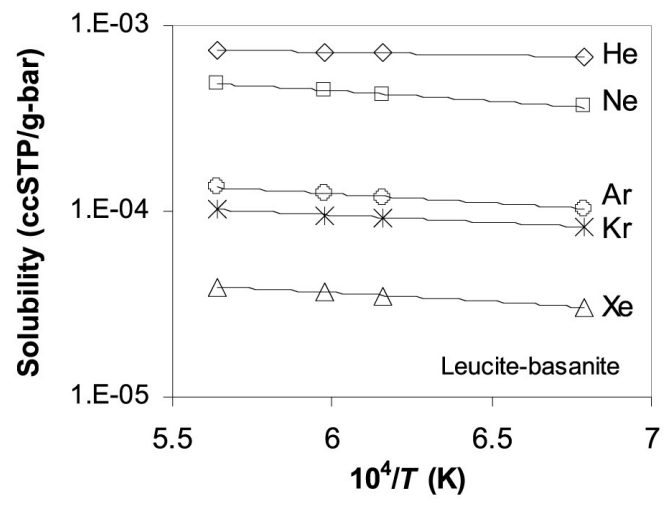

Fig. 10. Temperature effect on noble gas solubility in a basanite melt between 1200 and $1500^{\circ} \mathrm{C}$ at 0.1 $\mathrm{MPa}$. Data are from Lux (1987) and uncertainties are in the order of the symbol size. Curves were computed by using eq. (3.6) with parameters in table I. Solubility slightly increases with the increase of temperature.

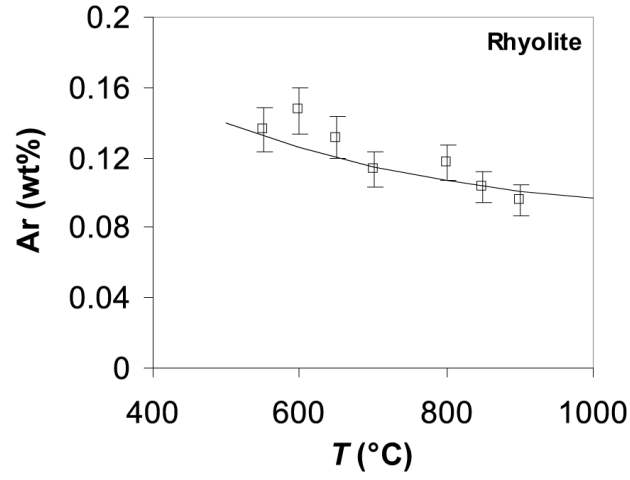

Fig. 11. Dissolved Ar in a rhyolite glass at 120-130 $\mathrm{MPa}$ as a function of temperature (data from Carroll and Stolper, 1993). Curves were computed by using eq. (3.6) with parameters in table I. Solubility displays a slightly negative relation with the increase of temperature.

see fig. 11), as well in $\mathrm{Na}_{2} \mathrm{O}-\mathrm{SiO}_{2}, \mathrm{Na}_{2} \mathrm{O}-\mathrm{CaO}-$ $\mathrm{SiO}_{2}, \mathrm{Na}_{2} \mathrm{O}-\mathrm{MgO}-\mathrm{SiO}_{2}$ melts (White et al., 1989; Shibata et al., 1988). All the described effects are normally more pronounced for heavier noble gases. The dissolution of a noble gas atom in the silicate melt can be usefully divided into two steps, each having its own enthalpy variation: i) the creation of a hole to accommodate a gas atom in the melt structure, and ii) the transfer of the atom into the hole. The former step needs energy, namely its enthalpy variation is positive; instead, moving an atom from a gas into a more condensed phase involves the evolution of heat and a negative $\Delta H^{\circ}$ sign. The whole enthalpy of solution is the sum of the two terms and its sign will depend on which contribution is dominant. Glasses and silica-rich melts have open structures, so we can expect that only a small contribution of energy is needed to create cavities inside. Moving atoms into the melt will be the energetically dominant process and, in view of the negative $\Delta H^{\circ}$ sign of such a process, we can explain the negative dependence of solubility on temperature. Opposite considerations can be made to explain the direct solubility-temperature relationship of less polymerized, alkali-rich melts, where a few pre-existing large holes are available and energy has to be spent to create or enlarge cavities. 


\subsection{Size distribution of solubility sites}

Several researchers (Shackelford and Masaryk, 1978; Shackelford and Brown, 1980; Shackelford, 1982; Nakayama and Shackelford, 1990; Carroll and Stolper, 1993) used the different solubilities among the noble gases as a gas-probe to investigate the distribution of hole size in vitreous silica and natural silicate melts. The logarithm of noble gas solubility displays a linear relation with the atomic radius (fig. 5), meaning that hole sizes result as having a log-normal distribution. The mode shifts towards higher hole size with increasing ionic porosity, thus large holes become more common than small ones and the solubility of heavier noble gases increases more quickly with respect to that of light gases. In accordance with the above conclusions, a numerical simulation of the interstitial structure of silica glass confirmed the log-normal distribution (Chan and Elliot, 1991).

Nuccio and Paonita (2000) assumed that the $m$ and $n$ parameters in eq. (3.3) are composition-independent for all noble gases, in accordance with what was experimentally verified for helium. In these conditions, their extended ionic porosity model for helium solubility in $\mathrm{H}_{2} \mathrm{O}-\mathrm{CO}_{2}$ bearing melts is valid for other noble gases. They calculated that a low percent of water in a melt causes an exponential increase of the number of large holes, as a consequence of potential structural modifications of the melt. These conclusions need to be proved using solubility data for noble gases having a large atomic radius.

\section{Implications in modeling magma degassing}

Several elements in magmas are able to form chemical species which may be exsolved in vapor phases $(\mathrm{H}, \mathrm{C}, \mathrm{O}, \mathrm{S}$ mainly, halogens, nitrogen, noble gases etc.; Gerlach and Nordilie, 1975; Giggenbach, 1996). These elements can react with the liquid forming chemical bonds (i.e. $\mathrm{OH}$ groups), or they exist under the form of volatile atomic or molecular species dissolved in the silicate melt (i.e. molecular $\mathrm{H}_{2} \mathrm{O}$, noble gases). Any dissolved volatile species (true or po- tential) is characterized by its own vapor pressure, which depends directly upon its concentration in the melt. Magma reaches supersaturation when the sum of the vapor pressures of the individual volatiles becomes higher than the total pressure of the system, as a consequence of ascent and depressurization of the melt (Carroll and Webster, 1994). In such conditions, the magma is potentially able to exsolve a vapor phase. As $\mathrm{H}_{2} \mathrm{O}$ and $\mathrm{CO}_{2}$ are the most abundant volatiles in natural magmatic systems, the assessment of magma saturation has been modeled as a gas mixture of these two compounds (Papale, 1999), although sulfur could have significant effects when its concentrations reach several weight percent in the system (Moretti et al., 2003).

When the vapor phase exsolves, minor volatiles are partitioned between the silicate liquid and the coexisting vapor, depending upon their solubilities. In fact, early vapor is strongly enriched in highly volatile species, which are consequently depleted in the melt (Giggenbach, 1996). The more soluble species are only able to exsolve into the gas phase during the late stages of degassing. As a consequence, less sol-

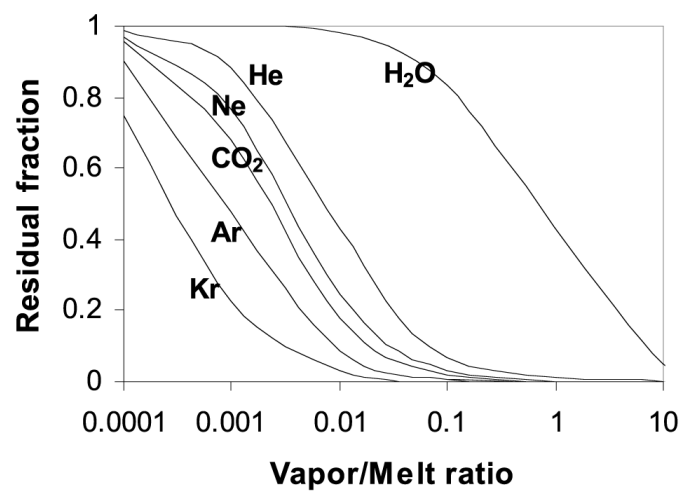

Fig. 12. Fraction of noble gases remaining in a tholeiitic melt with respect to the amount of exsolved vapor during a closed system degassing. Vapor/melt ratio is the volume of gas phase exsolved per volume unit of melt. Adopted equations for calculations were those by Giggenbach (1996), as well as the $\mathrm{H}_{2} \mathrm{O}$ and $\mathrm{CO}_{2}$ solubilities. $\mathrm{CO}_{2}$ solubility causes $\mathrm{CO}_{2}$ to degas before light noble gases, whereas $\mathrm{H}_{2} \mathrm{O}$ is much more soluble and is exsolved during late degassing. 
uble, heavy noble gases ( $\mathrm{Ar}, \mathrm{Kr}, \mathrm{Xe}$ ) are degassed earlier, whereas $\mathrm{He}$ and $\mathrm{Ne}$ degassing occurs later (fig. 12).

This solubility-controlled fractionation of the noble gases is much more significant if infinitesimal aliquots of volatiles are exsolved in equilibrium from the liquid phase and immediately removed, thereby creating open system degassing conditions. However, this behavior is also evident during closed system degassing processes, during which the exsolved vapor stays in contact with the melt throughout the degassing process (Carroll and Webster, 1994). Noble gas fractionation in open system degassing can be modeled by applying the typical Rayleigh distillation process. By considering two noble gases $i$ and $j$, the extent of fractionation between two gases is related to the residual fraction of one of the two volatiles

$$
\frac{C_{i}}{C_{j}}=\left(\frac{C_{i}}{C_{j}}\right)_{0}\left(\frac{C_{i}}{C_{i, 0}}\right)^{\left(1-\frac{K_{j}}{K_{i}}\right)}
$$

where $C$ is the volatile concentration in melt $(m)$; subscript $«^{0} »$ refers to initial conditions (undegassed parental melt) and $K$ is the Henry's constant. Calculations by eq. (4.1) have been applied to ratios between noble gases as a function of the total content of one noble gas in basalts (Taylor, 1986; Sarda and Graham, 1990; Carroll and Webster, 1994; Marty, 1995; Giggenbach, 1996; Burnard, 1999; Moreira and Sarda, 2000). By writing two Rayleigh equations for a ternary system, such as $\mathrm{He}-\mathrm{Ar}-\mathrm{CO}_{2}$, and coupling them, it can be shown that a plot of $\ln \left(\mathrm{Ar} / \mathrm{CO}_{2}\right)$ versus $\ln (\mathrm{Ar} / \mathrm{He})$ yields a straight line with a slope dependent upon the solubility ratios among the gases and an intercept dependent upon the $\mathrm{Ar} / \mathrm{CO}_{2}$ and $\mathrm{Ar} / \mathrm{He}$ ratios in the pristine undegassed melt (Burnard, 1999, 2001).

In a closed system, vesicles of an exsolved vapor remain in the melt, so the total amount of gas does not vary. Models have been developed that take into account the mass balance among the total amount of noble gas, its dissolved concentration and the volume of exsolved vapor per mass unit of melt (Jambon et al., 1986; Sarda and Moriera, 2002). By coupling Henry's Law to the mass balance, the fractionation be- tween noble gases can be related to the vesicularity of the melt (the volume of vapor phase exsolved per volume unit of melt)

$$
\frac{C_{i}}{C_{j}}=\frac{C_{i, 0}}{C_{j, 0}} \times \frac{K_{j}}{K_{i}} \times \frac{V^{*}+\rho T_{e} /\left(T_{0} K_{j}\right)}{V^{*}+\rho T_{e} /\left(T_{0} K_{i}\right)}
$$

where $T_{0}$ is equal to $273 \mathrm{~K} ; T_{e}$ is the temperature of the gas-melt equilibrium; $\rho$ is the density of the silicate melt (assumed constant), and $V^{*}$ is the melt vesicularity.

The above models have been frequently applied to study degassing on spatial scales from local to planetary. For example, investigations were performed on the gas phase trapped in vesicles and dissolved in glasses recovered from Middle-Oceanic Ridge Basalts (MORB) and Oceanic Island Basalts (OIB) (Jambon et al., 1986; Taylor, 1986; Sarda and Graham, 1990; Carroll and Webster, 1994; Giggenbach, 1996; Burnard, 1999, 2001; Honda and Patterson, 1999; Moreira and Sarda, 2000; Sarda and Moriera, 2002). Furthermore, constraints were obtained on the outgassing history of the mantle and its primordial composition. The higher $\mathrm{He} / \mathrm{Ar}$ ratios in MORB glasses with respect to their production/accumulation rate in the mantle (due to $\mathrm{K}$ and $\mathrm{U}$ decay), have normally been explained by degassing processes (Jambon et al., 1985), because Ar is preferentially degassed in respect of He. On this basis, Moriera and Sarda (2000) focused on the different degassing modalities that occur from MORB and from mantle plumes, the former degassing as a closed system, and the latter as an open-system Rayleigh-type process. However, some questions have been raised about this «degassing» hypothesis, namely that higher $\mathrm{He} / \mathrm{Ar}$ ratios occur at higher He contents (Honda and Patterson, 1999) and in basalts erupted at greater depths (Fisher, 1997). Solubility controlled degassing does not explain these constraints, whereas mechanisms of helium diffusion from mantle minerals or crystals in basalt melts have been hypothesized (Matsuda and Marty, 1995; Fisher, 1997; Honda and Patterson, 1999). In fact, Moreira and Sarda (2000) and Sarda and Moreira (2002) have suggested that the geochemical pattern of noble gas abundances in MORB is consistent with equilibrium vesiculation followed by 
various episodes of bubble loss, in accordance with the early model by Sarda and Graham (1990). However, Sarda and Moreira (2002) have also suggested that helium solubility should be two times higher than that experimentally measured at $0.1 \mathrm{MPa}$, and that $\mathrm{Ar}$ and $\mathrm{Ne}$ solubilities should be lower by factors of 3.5 and 7 , respectively. This opposite variation in solubilities makes their hypothesis about a pressure effect on solubility rather unlikely. Burnard (1999) moves criticisms on the experimental values of solubilities too, providing evidence that the noble gas $/ \mathrm{CO}_{2}$ solubility ratio has to be higher than experimentally measured. Nevertheless, a new view on noble gas data from MORB takes into account the size of the vesicles, as small bubbles should represent the previous extent of the degassing with respect to large vesicles (Burnard, 2001). Sequential crushing of basalts allows for the analysis of gas from progressively smaller bubbles, which can be used to determine the trajectory of the degassing. Preliminary data seem to reconcile with predicted solubility-controlled fractionation studies (Burnard, 2001).

The foregoing discussion stresses how noble gas abundances from natural samples are used as a reference point and as a check of experimental results on noble gas solubilities. It also highlights the wide use of the noble gas solubility data in Earth Sciences problems and the strong inferences they provide. Considering the fact that the experimental conditions do not match the geological ones, degassing models that use such data must be applied very carefully. Equations (4.1) and (4.2) describe how noble gases are partitioned in a vapor while they are progressively exsolved, regardless of: i) what type of volatiles dominate the vapor and if they behave non-ideally in such a gas mixture, ii) changes in concentration and, above all, in solubility due to the exsolution of the main volatiles. Application to MORB degassing could disregard the second conditions, at least for a first approximation, because the amounts of $\mathrm{H}_{2} \mathrm{O}$ and $\mathrm{CO}_{2}$ in these melts are lower than $1 \mathrm{wt} \%$ at least for $P<1 \mathrm{GPa}$. However, MORB degassing should take into account the noble gas fugacity in $\mathrm{CO}_{2}$-dominated vapor. Bottinga and Javoy (1990) discussed the exsolution of a non-ideal $\mathrm{H}_{2} \mathrm{O}-\mathrm{CO}_{2}-\mathrm{He}-\mathrm{Ar}$ mixture from bas-altic melts, although the $\mathrm{H}_{2} \mathrm{O}$ and $\mathrm{CO}_{2}$ effects on noble gas solubility were not considered. Nuccio and Paonita (2001) started from the already discussed model for noble gas solubility in $\mathrm{H}_{2} \mathrm{O}$ $\mathrm{CO}_{2}$ bearing melts (Nuccio and Paonita, 2000; see Section 3.1). The authors obtained an equation that allowed them to calculate the concentration of noble gas in an exsolved $\mathrm{H}_{2} \mathrm{O}-\mathrm{CO}_{2}$ mixed vapor as a function of the dissolved concentration of $\mathrm{H}_{2} \mathrm{O}, \mathrm{CO}_{2}$ and noble gas in melt and their total amounts in the vapor+melt system. Thus, the authors numerically simulated the degassing of multicomponent $\mathrm{H}_{2} \mathrm{O}-\mathrm{CO}_{2}$-no-

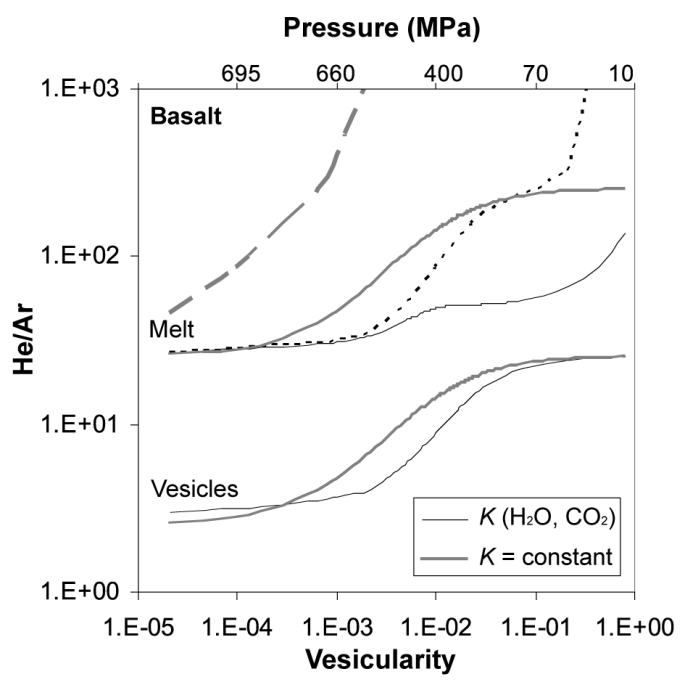

Fig. 13. He/Ar fractionation during closed system degassing of basaltic melt at $1200^{\circ} \mathrm{C}$. Initial $\mathrm{He} / \mathrm{Ar}$ ratio was 3 . Thick grey lines were computed by using the model of Jambon et al. (1986) (eq. (4.2) in the text), assuming noble gas solubilities were not affected by the presence of the main volatiles ( $K=$ constant) and ideal gas behavior. Thin black lines were computed on the basis of the model by Nuccio and Paonita (2001), which accounts for these effects. In this model, the initial conditions were $85 \mathrm{~mol} \% \mathrm{CO}_{2}$ in the $\mathrm{H}_{2} \mathrm{O}-\mathrm{CO}_{2}$ mixed vapor (noble gases are computed as minor species) at $700 \mathrm{MPa}$ pressure. Black thin lines for melt and vesicles approach each other at low pressure, due to the effect of water that makes the solubilities of noble gases more similar. Dashed curves were computed for an open system (grey line by Jambon et al., 1986 model black line by Nuccio and Paonita, 2001). 


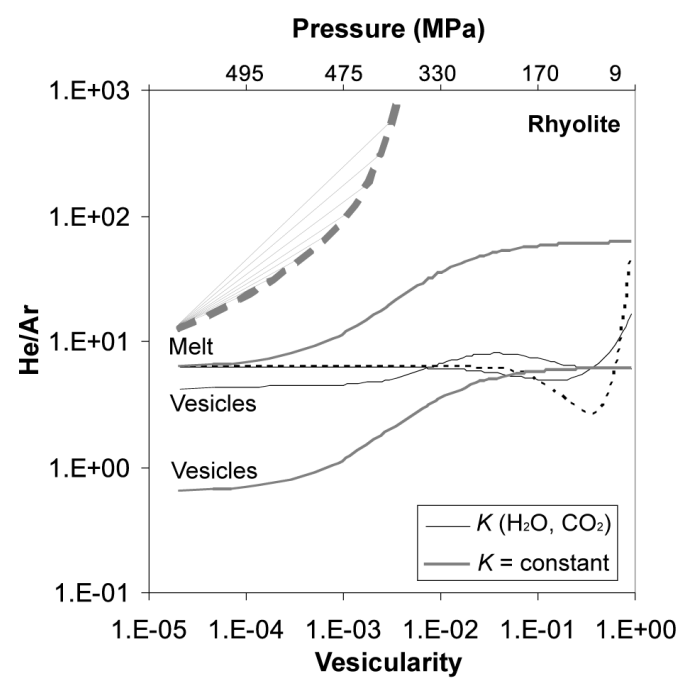

Fig. 14. $\mathrm{He} / \mathrm{Ar}$ fractionation during closed system degassing of rhyolitic melt at $1000^{\circ} \mathrm{C}$. Curves as in fig. 13. In the calculation using the model by Nuccio and Paonita (2001), initial conditions were $40 \mathrm{~mol} \%$ $\mathrm{CO}_{2}$ in $\mathrm{H}_{2} \mathrm{O}-\mathrm{CO}_{2}$ mixed vapor (noble gases are computed as minor species) at $500 \mathrm{MPa}$ pressure. The higher amount of dissolved water (6 wt \%) in respect of the basaltic melt amplifies the discussed water effect, causing very low $\mathrm{He} / \mathrm{Ar}$ fractionation.

ble gas mixtures from depressurizing magmas. As a result, remarkable differences were highlighted between the comprehensive approach and simpler models (figs. 13-15). In spite of the constant ratio between $\mathrm{He} / \mathrm{Ar}$ in melt and vesicles computed by the simpler model (namely, $\left.(\mathrm{He} / \mathrm{Ar})_{\text {gas }} /(\mathrm{He} / \mathrm{Ar})_{\text {melt }}=\mathrm{K}_{\mathrm{He}} / \mathrm{K}_{\mathrm{Ar}}\right)$, curves from the more complex model come closer at low pressure. In fact, taking into account the fact that high pressure causes very different solubility among noble gases and that dissolved water has the opposite effect, a few wt\% of dissolved water at low pressure are able to significantly reduce the solubility difference between $\mathrm{He}$ and Ar (fig. 13 and see Section 3.1). As a consequence, noble gases may fractionate less than predicted by simpler calculations, depending on the composition of the magma and on the main volatiles it contains. The application of the model to very different contexts, from silicic to basaltic volcanoes (Nuccio and Paonita 2001; Caracausi et al., 2003), shows how the inert gas content of outgassed magmatic volatiles may produce information and constraints on deep magmatic conditions: magma pressure and depth over time, degassing and volatile content, melt composition and temperature. The current research aims at developing approaches to describe saturation surfaces in more complex systems, including sulfur and halogens. On this basis, the solubility of noble gases in such systems progressively more similar to true geological conditions, will have to be theoretically and experimentally investigated, allowing for the development of more refined degassing models.

Finally, vapor-melt equilibrium for noble gases has been assumed in all the discussed models. Experimental observations and theoretical modeling have been performed to investigate the growth of steam bubbles in silicate liquids (Bottinga and Javoy, 1990; Proussevich and Sahagian, 1996, 1998; Gardner et al., 1999, 2000). Bubbles seem to maintain chemical equilibrium with the surrounding melt even in those silicic magmas whose ascent rates are

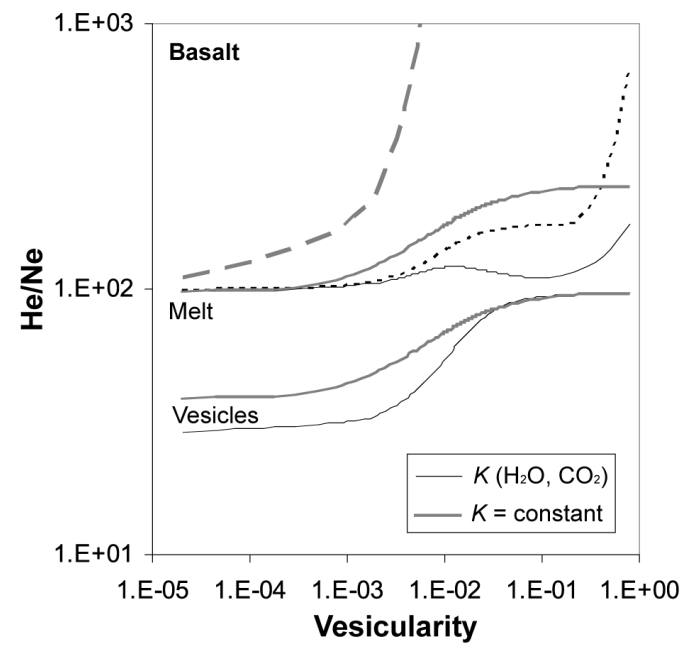

Fig. 15. He/Ne fractionation during closed system degassing of basaltic melt at $1200^{\circ} \mathrm{C}$. Curves and conditions as in fig. 13. The behavior is qualitatively similar to that discussed in the case of argon, although the fractionation is more modest. 
three orders of magnitude higher than their common pre-eruptive values $(\sim 0.01 \mathrm{~m} / \mathrm{s})$, whereas non-equilibrium exsolution could occur during explosive rising. Nevertheless, there is a total lack both of experimentation and models for the investigation of possible disequilibrium fractionation among noble gases. In addition, noble gas diffusion in melts containing $\mathrm{H}_{2} \mathrm{O}$ and/or $\mathrm{CO}_{2}$, which is crucial to describe such processes, is also poorly known.

\section{Upcoming research}

Although our knowledge of noble gas solubility in magmas has significantly improved over the last twenty years, a lot of work has yet to be accomplished from both experimental and theoretical points of view. Magma is a multicomponent system carrying several volatile components in its gas phase; nevertheless our studies on the solubility of noble gases in such complex volatile-bearing systems are still in their early stages. Few experimental data are available regarding helium solubility in silicate melts coexisting with $\mathrm{H}_{2} \mathrm{O}-\mathrm{CO}_{2}$ mixed vapors. Although these studies are not comprehensive enough to fully describe and understand the effect of the main volatile components on noble gas solubility, they do highlight that it cannot be neglected. The dissolution of noble gases is strictly related to the availability of solubility sites in the silicate network and, due to the significant structural changes in melts caused by the main volatiles, $\mathrm{H}_{2} \mathrm{O}$ and $\mathrm{CO}_{2}$ may well have a very significant control over noble gas solubility.

On this basis, sulfur and chlorine (perhaps fluorine as well) may exhibit similar effects, however we lack critical information to evaluate them. As far as the gas phase is concerned, there are equations of state that can calculate the activity-composition relations for $\mathrm{Ar}$ in $\mathrm{H}$ $\mathrm{C}-\mathrm{S}-\mathrm{O}$ mixed vapor in a wide range of pressure and temperature conditions (Belenosko et al., 1992). More recently, equations have become available for noble gases in $\mathrm{H}-\mathrm{C}-\mathrm{S}-\mathrm{O}-$ halogens (Churakov and Gottschalk, 2003). Nevertheless, the activities of noble gas in $\mathrm{S}-\mathrm{Cl}$ bearing silicate melts are totally unknown, and there is a great need for experimentation in this field of research. In addition, the inadequate knowledge of the structural effect of sulfur and chlorine does not allow us to evaluate their influence on the distribution of the hole-size in melts and, as a consequence, on noble gas solubility. Regardless of the analytical method, the experimental determination of noble gas solubility in complex systems requires the charging of known amounts of volatiles inside capsules, in order to obtain vapor phases having similar compositions to those of magmatic ones. In view of this, the method of loading noble gases by gas-bearing glasses (see Section 2) should be broadly applicable to the investigation of the solubility of all noble gases (even $\mathrm{He}$ and $\mathrm{Ne}$ ) in melts up to very high pressures. Although the mass balance between the total and dissolved noble gas allows us to calculate the concentration of noble gas in vapor and then the partition coefficient, the ability to measure the content of noble gas in both the vapor and liquid phase becomes ever more important. In this respect, coupling in situ extraction techniques and mass spectrometry seems the most powerful tool, especially in investigating the solubility of light noble gases.

In addition, $X$-ray absorption techniques have started to provide insights into how noble gas atoms are accommodated in the silicate melt structure and the short-range order. Although these data do not produce a direct measurement of solubility, they are still able to constrain the parameters used in the statistical-mechanics solubility models. Such theoretical approaches give detailed information and explanations of the mechanism of noble gas dissolution in melt and thus they need to be further improved. Additional information could also come, in the future, from computer simulations of noble gas-bearing melts by using Molecular Dynamics (MD) methods, although a lot of work must be done to define pair potentials between the noble gas and the main particles of the melt by fitting experimental data or by performing ab-initio calculations. For this work, the expertise of mineralogists and materials scientists, interested in the considerable inferences of noble gas solubility on the structure of silicate glass and melt, could be very helpful. This co-operation should aim at developing several aspects having technological and 
commercial interests and involving the interaction of gas atoms with rigid glass materials. For instance, noble gases (He, Ar) are normally used in the growth of silicon-made materials for use in semiconductor devices, or with the aim of preventing gas inclusion formation during the manufacture of glass and ceramics. Ceramics are also porous enough to allow for noble gas permeation, allowing Magnetic Resonance Imaging (MRI) using laser-polarized noble-gas-testing of the structural integrity of the material. Large differences in the solubility and diffusion of the gases can be used to separate the components of gas mixtures.

Finally, an interesting field to be developed in the future involves the possible effects of disequilibrium during noble gas degassing from magmas. In their recent paper, Caracausi et al. (2003) show that the helium isotopic composition monitored in volcanic emissions at Mt. Etna displays variations over time, which cannot be referred to shallow secondary processes. Kinetic fractionation of helium isotopes during diffusion in growing bubbles has been suggested to explain this type of signal (Nuccio and Valenza, 1998; Caracausi et al., 2003). In fact, light ${ }^{3} \mathrm{He}$ atoms could diffuse at higher rates in growing bubbles with respect to heavier ${ }^{4} \mathrm{He}$ atoms. In the same way, the ratios between noble gases both in volcanic gases and fluid inclusions could be affected by a similar disequilibrium process, especially when taking into consideration that they have similar dissolution mechanisms and that there is a big difference between their atomic masses. Experiments on this topic are not simple and theoretical calculations, to be based on noble gas diffusion rates, require adequate knowledge of the effects of the main volatiles on noble gas diffusivity in silicate melts. A lot of effort still has to be made in this direction, which however seems very promising in its application to magmatic systems.

\section{Acknowledgements}

The author wishes to thank P.M. Nuccio for useful comments and suggestions. The review by D. Baker and C. Romano greatly improved the manuscript.

\section{REFERENCES}

Belenoshko, A. and S.K. Saxena (1992): A unified equation of state for fluids of C-H-O-N-S-Ar composition and their mixtures up to very high temperatures and pressures, Geochim. Cosmochim. Acta, 56, 3611-3626.

BoetTCher, S.L., Q. Guo and A. Montana (1989): A simple device for loading gases in high-pressure experiments, Am. Mineral., 74, 1383-1384.

BotTinga, Y. and M. JAVOY (1990): MORB degassing: bubble growth and ascent, Chem. Geol., 81, 255-270.

BraWER, S.A. and W.B. WhITE (1975): Raman spectroscopy investigation of the structure of silicate glasses, I. The binary silicate glasses, J. Chem. Phys., 63, 2421-2432.

Broadhurst, C.L., M.J. Drake, B.E. Hagee and T.J. BERNATOWICZ (1992): Solubility and partitioning of $\mathrm{Ne}, \mathrm{Ar}, \mathrm{Kr}$, and $\mathrm{Xe}$ in minerals and synthetic basalt melts, Geochim. Cosmochim. Acta, 56, 709-723.

Brooker, R.A., J.-A. Wartho, M.R. CARroll, S.P. KelLEY and D.S. DRAPER (1998): Prelimirary UVLAMP determinations of argon partition coefficients for olivine and clinopyroxene grown from silicate melts, Chem. Geol., 147, 185-200.

BURNARD, P. (1999): The bubble-by-bubble volatile evolution of two mid-ocean ridge basalts, Earth Planet. Sci. Lett., 174, 199-211.

BURNARD, P. (2001): Correction for volatile fractionation in ascending magmas: noble gas abundances in primary mantle melts, Geochim. Cosmochim. Acta, 65, 26052614.

Caracausi, A., F. Italiano, P.M. Nuccio, A. Paonita and A. Rizzo (2003): Evidence of deep magma degassing and ascent by geochemistry of peripheral gas emissions at Mt. Etna (Italy): assessment of the magmatic reservoir pressure, J. Geophys. Res., 108, 2463-2484.

CARroll, M.R. and D.S. DraPer (1994): Noble gases as trace elements in magmatic processes, Chem. Geol., 117, 37-56.

Carroll, M.R. and E.M. Stolper (1991): Argon solubility and diffusion in silica glass: implications for the solution behavior of molecular gases, Geochim. Cosmochim. Acta, 55, 211-225.

Carroll, M.R. and E.M. Stolper (1993): Noble gas solubilities in silicate melts and glasses: new experimental results for $\mathrm{Ar}$ and the relationship between solubility and ionic porosity, Geochim. Cosmochim. Acta, 57, 5039-5051.

Carroll, M.R. and J.D. Webster (1994): Solubilities of sulfur, noble gases, nitrogen, chlorine, and fluorine in magmas, in Volatiles in Magmas, edited by M.R. CARROLL and J.R. HollowAY, Rev. Mineral., 30, 231-279.

Carroll, M.R., S.R. Sutton, M.L. Rivers and D.S. Woolum (1993): A experimental study of krypton diffusion and solubility in silicic glasses, Chem. Geol., 109, 9-28.

Chamorro-Perez, E., P. Gillet and A. Jambon (1996): Argon solubility in silicate melts at very high pressures. Experimental set-up and preliminary results for silica and anorthite melts, Earth Planet. Sci. Lett., 145, 97107.

Chamorro-Perez, E., P. Gillet, A. Jambon, J. Bardo and P. MCMillan (1998): Low argon solubility in silicate 
melts at high pressure, Nature, 393, 352-355.

Chamorro, E.M., R.A. Brooker, J.A. WARTho, B.J. Wood, S.P. Kelley and J.D. Blundy (2002): Ar and K partitioning between clinopyroxene-silicate at $8 \mathrm{GPa}$, Geochim. Cosmochim. Acta, 66, 507-519.

ChAN, S.L. and S.R. Elliot (1991): Theoretical study of the interstice statistics of the oxygen sublattice in vitreous $\mathrm{SiO}_{2}$, Phys. Rev. B, 43, 4423-4432.

Chennaoui-Aoudjeane, H. and A. Jambon (1990): He solubility in silicate glasses at $250^{\circ} \mathrm{C}$ : a model for calculation, Eur. J. Mineral., 2, 539-545.

Churakov, S.V. and M. GotTschalk (2003): Perturbation theory based equation of state for polar molecular fluids, II. Fluid mixtures, Geochim. Cosmochim. Acta, 67, 2415-2425

De Santis, R., G.J.F. Breedveld and J.M. Prausnitz (1974): Thermodynamic properties of aqueous gas mixtures at advanced pressures, Ind. Eng. Chem. Process. Des. Develop., 13, 374-377.

Dixon, J.E., E.M. STOLPER and J.R. Holloway (1995): An experimental study of water and carbon dioxide solubilities in Mid-Ocean Ridge basaltic liquids, Part I. Calibration and Solubility models, J. Petrol., 36 (6), 1607-1631.

Doremus, H. (1966): Physical solubility of gases in fused silica, J. Am. Ceram. Soc., 49, 461-462.

DraPer, D.S. and M.R. CARRoll (1995): Argon diffusion and solubility in silicic glasses exposed to an Ar-He mixtures, Earth. Planet. Sci. Lett., 132, 15-24.

Frank, R.C., D.E. Swets and R.W. LeE (1961): Diffusion of neon isotopes in fused quartz, J. Chem. Phys., 35, 1451-1459.

FisHER, D.E. (1970): Heavy rare gas in a Pacific seamount, Earth Planet. Sci. Lett., 9, 331-335.

FisHER, D.E. (1997): Helium, argon and xenon in crushed and melted MORB, Geochim. Cosmochim. Acta, 61, 3003-3012.

GARDNER, J.E., M. HiLton and M.R. CARroll (1999): Experimental constrains on degassing of magma: isothermal bubble growth during continuous decompression from high pressure, Earth Planet. Sci. Lett., 168, 201-218.

GARDNER, J.E., M. HiLtON and M.R. CARROLl (2000): Bubble growth in highly viscous silicate melts during continuous decompression from high pressure, Geochim. Cosmochim. Acta, 64, 1473-1483.

Gerlach, T.M. and B.E. Nordilie (1975): The C-O-H-S gaseous system, Part I. Composition limits and trends in basaltic glasses, Am. J. Sci., 275, 353-376.

GigGENBACH, W.F. (1996): Chemical composition of volcanic gases, in Monitoring and Mitigation of Volcanic Hazards, edited by R. SCARPA and R. TILLING (Springer), 221-256.

Hayatsu, A. and C.E. Waboso (1985): The solubility of rare gases in silicate melts and implications for $\mathrm{K}-\mathrm{Ar}$ dating, in Terrestrial Noble Gases, edited by F.A. PoDOSEK, Chem. Geol., 52, 97-102.

Holloway, J.R. (1977): Fugacity and activity of molecular species in supercritical fluids, in Thermodynamics in Geology, edited by D.G. Fraser (Reidel Pub. Comp., Dordrecht-Holland, Boston).

Honda, M. and D.B. Patterson (1999): Systematic elemental fractionation of mantle-derived helium, neon and argon in mid-ocean ridge glasses, Geochim. Cosmochim. Acta, 63, 2863-2874.
IHINGER, P.D., Y. Zhang and E.M. STOLPER (1999): The speciation of dissolved water in rhyolitic melt, Geochim. Cosmochim. Acta, 63, 3567-3578.

JAMBON, A. (1987): He solubility in silicate melts: a tentative model of calculation, Chem. Geol., 62, 131-136.

JAmbon, A., H.W. Weber and F. BEgEMAN (1985): Helium and argon from an Atlantic MORB glass: concentration, distribution and isotopic composition, Earth Planet. Sci. Lett., 73, 255-267.

JAMBOn, A., H.W. WebER and O. BRAun (1986): Solubility of $\mathrm{He}, \mathrm{Ne}, \mathrm{Ar}, \mathrm{Kr}, \mathrm{Xe}$ in a basalt melt in the range of $1250-1600^{\circ} \mathrm{C}$ : geochemical implications, Geochim. Cosmochim. Acta, 50, 401-408.

Kelley, S.P., N.O. Arnaud and G. Turner (1994): High spatial resolution ${ }^{40} \mathrm{Ar} /{ }^{39} \mathrm{Ar}$ investigation of quartz, biotite and plagioclase using a new ultra-violet laser probe extraction technique, Geochim. Cosmochim. Acta, 58, 3519-3525.

KING, P.L. and J.R. Holloway (2002): $\mathrm{CO}_{2}$ solubility and speciation in intermediate (andesitic) melts: the role of $\mathrm{H}_{2} \mathrm{O}$ and composition, Geochim. Cosmochim. Acta, 66, $1627-1640$

KIRSTEN, T. (1968): Incorporation of rare gas in solidifying enstatite melts, J. Geophys. Res., 73, 2807-2810.

KoHn, S.C., R. DupreE and M.E. SMith (1989): A multinuclear magnetic resonance study of the structure of hydrous albite glasses, Geochim. Cosmochim. Acta, 53, 2925-2935

Kohn, S.C., M.E. SMith, P.J. Dirken, E.R.H. van EcK, A.P.M. Kentgens and R. DupreE (1998): Sodium environment in hydrous and dry albite glasses: improved ${ }^{23} \mathrm{Na}$ solid state NMR data and their implication for water dissolution mechanisms, Geochim. Cosmochim. Acta, 62, 79-87.

LANGE, R.M. and I.S.E. CharmichaEl (1987): Densities of $\mathrm{Na}_{2} \mathrm{O}-\mathrm{K}_{2} \mathrm{O}-\mathrm{CaO}-\mathrm{MgO}-\mathrm{FeO}-\mathrm{Fe}_{2} \mathrm{O}_{3}-\mathrm{Al}_{2} \mathrm{O}_{3}-\mathrm{TiO}_{2}-\mathrm{SiO}_{2}$ liquids: new measurements and derived partial molar properties, Geochim. Cosmochim. Acta, 51, 2931-2946.

LuX, G. (1987): The behavior of noble gases in silicate liquids: solution, diffusion, bubbles, and surface effects, with applications to natural samples, Geochim. Cosmochim. Acta, 51, 1549-1560.

MARTY, B. (1995): Nitrogen content of the mantle inferred from $\mathrm{N}_{2}$-Ar correlation in oceanic basalts, Nature, 377, 326-329.

Matsuda, J. and B. MARTy (1995): The ${ }^{40} \mathrm{Ar} /{ }^{36} \mathrm{Ar}$ ratio of the undepleted mantle: a reevaluation, Geophys. Res. Lett., 22, 1937-1940.

McMillan, P.F. (1994): Water solubility and speciation models, in Volatiles in Magmas, edited by M.R. CARROLL and J.R. Holloway, Rev. Mineral., 30, 131-156.

Montana, A., Q. Guo, S.L. Boettcher, B.S. White and M. BREARLEY (1993): Xe and Ar in high-pressure silicate liquids, Am. Mineral., 78, 1135-1142.

MoreIRA, M. and P. SARDA (2000): Noble gas constraints on degassing processes, Earth Planet. Sci. Lett., 176, 375-386.

Moretti, R., P. Papale and G. OtTOnello (2003): A model for the saturation of C-O-H-S fluids in silicate melts, in Volcanic Degassing, edited by C. OPPENHEIMER, D.M. Pyle and J. BARClay, Geol.Soc. Spec. Publ.213, 81-101.

Mysen, B.O., D. VIRGO and F.A. SEIFERT (1985): Relation- 
ships between properties and structure of aluminosilicate melts, Am. Mineral., 70, 88-105.

NaKayama, G.S. and J.F. ShackelFord (1990): Solubility and diffusivity of argon in vitreous silica, J. Non-Cryst. Solids, 126, 249-260.

NowAK, M. and H. BEHRENS (1995): The speciation of water in haplogranitic glasses and melts determined by in situ near-infrared spectroscopy, Geochim. Cosmochim. Acta, 59, 3445-3450.

NowAK, M. and H. BeHrens (2001): Water in rhyolitic magmas: getting a grip on a slippery problem, Earth Planet. Sci. Lett., 184, 515-522.

Nuccio, P.M. and A. PAONITA (2000): Investigation of the noble gas solubility in $\mathrm{H}_{2} \mathrm{O}-\mathrm{CO}_{2}$ bearing silicate liquids at moderate pressure, II. The Extended Ionic Porosity (EIP) model, Earth Planet. Sci. Lett., 183, 499-512.

NucCIO, P.M. and A. PAONITA (2001): Magmatic degassing of multicomponent vapors and assessment of magma depth: application to Vulcano Island (Italy), Earth Planet. Sci. Lett., 193, 467-481.

NucCio, P.M. and M. VAlenZA (1998): Magma degassing and geochemical detection of its ascent, in Water-Rock Interaction, edited by G.B. AREHART and J.R. HuLSTON (Balkema), 475-478.

Oglesby, J.V., S. Kroeker and J.F. Stebbins (2001): Potassium hydrogen disilicate: a possible model compound for ${ }^{17} \mathrm{O}$ NMR spectra of hydrous silicate glasses, $\mathrm{Am}$. Mineral., 86, 341-347.

Paonita, A., G. Gigli, D. Gozzi, P.M. Nuccio and R. TRIGILA (2000): Investigation of $\mathrm{He}$ solubility in $\mathrm{H}_{2} \mathrm{O}-\mathrm{CO}_{2}$ bearing silicate liquids at moderate pressure: an experimental method, Earth Planet. Sci. Lett., 181, 595-604.

PAPAle, P. (1999): Modeling of the solubility of a two component $\mathrm{H}_{2} \mathrm{O}+\mathrm{CO}_{2}$ fluid in silicate liquids, Am. Mineral., 84 (4), 477-492.

Proussevitch, A.A. and D.L. Sahagian (1996): Dynamics of coupled diffusive and decompressive bubble growth in magmatic systems, J. Geophys. Res., 101, 17447-17456.

Proussevitch, A.A. and D.L. SAHAgIan (1998): Dynamics and energetics of bubble growth in magmas: analytical formulation and numerical modeling, J. Geophys. Res., 103, 18223-18251.

Roselieb, K., W. RAmmensee, H. Buttner and M. RosenHAUER (1992): Solubility and diffusion of noble gases in vitreous albite, Chem. Geol., 96, 241-266.

Roselieb, K., W. Rammensee, H. Buttner and M. RosenHAUER (1995): Diffusion of noble gases in melts of the system $\mathrm{SiO}_{2}-\mathrm{NaAlSi}_{2} \mathrm{O}_{6}$, Chem. Geol., 120, 1-13.

Sarda, P. and D. Graham (1990): Mid-oceanic ridge popping rocks: implications for degassing at ridge crests, Earth Planet. Sci. Lett., 97, 268-289.

SARDA, P. and M. MorieIRA (2002): Vesiculation and vesicle loss in mid-ocean ridge basalt glasses: $\mathrm{He}, \mathrm{Ne}, \mathrm{Ar}$ elemental fractionation and pressure influence, Geochim. Cosmochim. Acta, 66, 1449-1458.

SCHMIDT, B.C. and H. KePPLER (2002): Experimental evidence for high noble gas solubilities in silicate melts under pressures, Earth Planet. Sci. Lett., 195, 277-290.

SCHMidT, B.C., T. RIEMER, S.C. KoHn, H. BEHRENS and R. DUPREE (2000): Different water solubility mechanisms in hydrous glasses along the quartz-albite join. Evidence from NMR spectroscopy, Geochim. Cosmochim. Acta, 64, 513-526.
SCHMidt, B.C., T. Riemer, S.C. Kohn, F. Holtz and R. DUPREE (2001): Structural implications of water dissolution in haplogranitic glasses from NMR spectroscopy: influence of total water content and mixed alkali effect, Geochim. Cosmochim. Acta, 65, 2949-2964.

SHACKELFORD, J.F. (1982): A gas probe analysis of structure in bulk and surface layers of vitreous silica, J. NonCryst. Solids, 49, 299-307.

SHACKELFORD, J.F. (1999): Gas solubility in glasses - Principles and structural implications, J. Non-Cryst. Solids, 253, 231-241.

SHACKELFORD, J.F. and B.D. BRown (1980): A gas probe analysis of structure in silicate glasses, J. Am. Ceram. Soc., 63, 562-565.

SHACKELFORD, J.F. and J.S. MASARYK (1978): The interstitial structure of vitreous silica, J. Non-Cryst. Solids, 30, 127-139.

Shackelford, J.F., P.L. Studt and R.M. FulRath (1972): Solubility of gases in glass II. He, $\mathrm{Ne}$, and $\mathrm{H}_{2}$ in fused silica, J. Appl. Phys., 43, 1619-1626.

ShanNON, R.D. and C.T. PREwITT (1969): Effective ionic radii in oxides and fluorides, Acta Cryst., 25, 925-946.

SHELBy, J.E. (1972a): Helium migration in natural and synthetic vitreous silica, J. Am. Ceram. Soc., 55, 61-64.

Shelby, J.E. (1972b): Neon migration in vitreous silica, $J$. Am. Ceram. Soc., 55, 167-170.

SHELBY, J.E. (1973): Effects of phase separation on helium migration in sodium silicate glasses, J. Am. Ceram. Soc., 56, 263-266.

Shelby, J.E. (1974): Helium diffusion and solubility in $\mathrm{K}_{2} \mathrm{O}-\mathrm{SiO}_{2}$ glasses, J. Am. Ceram. Soc., 57, 236-263.

Shelby, J.E. (1976): Pressure dependence of helium and neon in vitreous silica, J. Appl. Phys., 47, 135-139.

SHeN, A. and H. KePPLER (1995): Infrared spectroscopy of hydrous silicate melts to $1000^{\circ} \mathrm{C}$ and $10 \mathrm{kbar}$ : direct observation of $\mathrm{H}_{2} \mathrm{O}$ speciation in a diamond-anvil cell, Am. Mineral., 80, 1335-1338.

Shibata, T., E. Takahashi and J. Matsuda (1996): Noble gas solubility in binary $\mathrm{CaO}-\mathrm{SiO}_{2}$ system, Geophys. Res. Lett., 23, 3139-3142.

Shibata, T., E. TAKahashi and J. Matsuda (1998): Solubility of neon, argon, krypton and xenon in binary and ternary silicate system: a new view on noble gas solubility, Geochim. Cosmochim. Acta, 62, 1241-1253.

STUDT, P.L., J.F. SHACKELFORD and R.M. FulRATH (1970): Solubility of gases in glass - A monoatomic model, $J$. Appl. Phys., 44, 2777-2780.

SyKES, D. and J. KUBICKI (1993): A model for $\mathrm{H}_{2} \mathrm{O}$ solubility mechanisms in albite melts from infrared spectroscopy and molecular orbital calculations, Geochim. Cosmochim. Acta, 57, 1039-1052.

TAYLOR, B.E. (1986): Magmatic volatiles: isotopic variations of $\mathrm{C}, \mathrm{H}$, and $\mathrm{S}$, Rev. Mineral., 16, 185-225.

VIRGo, D., B.O. MysEn and I. Kushiro (1980): Anionic constitution of 1-atmosphere silicate melts: implications for the structure of igneous melts, Science, 208, 1371-1373.

Walter, H., K. Roselieb, H. Buttner and M. RosenHauer (2000): Pressure dependence of the solubility of Ar and $\mathrm{Kr}$ in melts of the system $\mathrm{SiO}_{2}-\mathrm{NaAlSi}_{2} \mathrm{O}_{6}$, Am . Mineral., 85, 1117-1127.

White, B.S., M. Brearley and A. Montana (1989): Solubility of Argon in silicate liquids at high pressures, Am. Mineral., 74, 513-529. 
Withers, A.C., Y. ZhANG and H. BeHRENS (1999): Reconciliation of experimental results on $\mathrm{H}_{2} \mathrm{O}$ speciation in rhyolitic glass using in situ and quenching techniques, Earth Planet. Sci. Lett., 173, 343-349.

Wulf, R., G. Calas, A. Ramos, H. Buttner, K. Roselieb and M. RosenHAUER (1999): Structural environment of krypton dissolved in vitreous silica, Am. Mineral., 84, 1461-1463.
ZENG, Q., H. NeKVASIL and C.P. GREY (1999): Proton environments in hydrous aluminosilicate glasses: a ${ }^{1} \mathrm{H}$ MAS, ${ }^{1} \mathrm{H} /{ }^{27} \mathrm{Al}$, and ${ }^{1} \mathrm{H} /{ }^{23} \mathrm{Na}$ TRAPDOR NMR study, $J$. Phys. Chem. B, 103, 7406-7415.

ZENG, Q., H. NEKVASIL and C.P. GREY (2000): In support of a depolymeryzation model for water in sodium aluminosilicate glasses: information from NMR spectroscopy, Geochim. Cosmochim. Acta, 64, 883-896. 